\title{
Tracing the tropics across land and sea: Permian to present
}

\author{
ALFRED M. ZIEGLER, GIDON ESHEL, P. McALLISTER REES, THOMAS A. ROTHFUS, DAVID B. ROWLEY \\ AND DAVID SUNDERLIN
}

LETHAIA

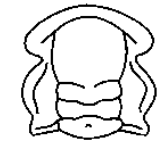

Ziegler, A.M., Eshel, G., McAllister Rees, P., Rothfus, T.A., Rowley, D.B. \& Sunderlin, D. 200309 12: Tracing the tropics across land and sea: Permian to present. Lethaia, Vol. 36, pp. 227-254. Oslo. ISSN 0024-1164.

\begin{abstract}
The continuity through the past 300 million years of key tropical sediment types, namely coals, evaporites, reefs and carbonates, is examined. Physical controls for their geographical distributions are related to the Hadley cell circulation, and its effects on rainfall and ocean circulation. Climate modelling studies are reviewed in this context, as are biogeographical studies of key fossil groups. Low-latitude peats and coals represent everwet climates related to the Intertropical Convergence Zone near the Equator, as well as coastal diurnal rainfall systems elsewhere in the tropics and subtropics. The incidence of tropical coals and rainforests through time is variable, being least common during the interval of Pangean monsoonal climates. Evaporites represent the descending limbs of the Hadley cells and are centred at $10^{\circ}$ to $40^{\circ}$ north and south in latitudes that today show an excess of evaporation over precipitation. These deposits coincide with the deserts as well as seasonally rainy climates, and their latitudinal ranges seem to have been relatively constant through time. Reefs also can be related to the Hadley circulation. They thrive within the regions of clear water associated with broad areas of downwelling which are displaced toward the western portions of tropical oceans. These dynamic features are ultimately driven by the subtropical high-pressure cells which are the surface signature of the subsiding branches of the Hadley circulation. Carbonates occupy the same areas, but extend into higher latitudes in regions where terrestrial surface gradients are low and clastic runoff from the land is minimal. We argue that the palaeo-latitudinal record of all these climate-sensitive sediment types is broadly similar to their environments and latitudes of formation today, implying that dynamic effects of atmospheric and oceanic circulation control their distribution, rather than temperature gradients that would expand or contract through time. $\square$ Cenozoic, Mesozoic, palaeoclimatology, palaeogeography, Permian, Tropics.
\end{abstract}

Alfred M. Ziegler, Gidon Eshel, P. McAllister Rees, Thomas A. Rothfus, David B. Rowley [rowley@geosci.uchicago.edu] \& David Sunderlin (corresponding author), Department of the Geophysical Sciences, University of Chicago, 5734 S. Ellis Avenue, Chicago, Illinois 60637, USA; 12th August 2002, revised 3rd June 2003
The tropics are usually defined as the regions between, or near, the north and south Tropics of Cancer and Capricorn at $23.5^{\circ}$ from the equator, an area that constitutes about $40 \%$ of the Earth's surface. At the same time, the floras and faunas characteristic of the tropics are not constrained to this zone and, indeed, they also extend to temperate latitudes in limited parts of the world. During certain times in the geological past, these poleward excursions seem to have been more extreme, while at other times biomes we commonly refer to as 'tropical', such as the rainforest, were limited or absent in the tropics. Geologists are thus faced with a real conundrum in identifying the tropics through the past because it is tempting to define these zones using fossils.

The archetypal tropical biome is the rainforest because it is the most diverse and productive flora of the terrestrial realm, yet covers only one-third of the tropical land area today (Morley 2000). While they tend to be centred on the equator, rainforest floras may also extend along coasts beyond the tropics to $30^{\circ}$ (e.g. southern Brazil; Negrelle 2002). The record latitude for a 'tropical rainforest' of the geological past is $50^{\circ}$ during the Paleocene-Eocene transition of North America (Wolfe 1985). In fact, Wolfe included a world map showing this biome extending across the equator to similar temperate latitudes in the southern hemisphere, encompassing about $75 \%$ of the land surface. Morley (2000) provided a more realistic view by inserting the subtropical desert belts on his maps and redefining the rainforests poleward of the deserts as 'Boreotropical' and 'Southern Megathermal'. Another refinement would be to subdivide the vegetated zones into 'seasonally dry' and 'everwet'.

In the marine realm the reef is the archetypal tropical biome because of the extraordinary diversity of invertebrates, calcareous-secreting algae and fish. However, reefs are generally absent from the eastern 
sides of oceans where cooler waters and upwelling conditions favour surface dwelling communities. Some of the highest recorded coral diversities are outside the orbitally defined tropics today (Rosen 1988), and reefs are developed at $32.5^{\circ} \mathrm{N}$ (Bermuda) and $31.5^{\circ} \mathrm{S}$ (Lord Howe Island). It is generally assumed that reefs are restricted to temperatures of $18^{\circ}-20^{\circ} \mathrm{C}$, and that they should be expected at higher latitudes during warm periods of the past. Ziegler et al. (1984) argued that this expectation is not met in the geological record, and theorized that latitudinal limits of light refraction and penetration to the sea floor restrict these bottom-dwelling organisms. Photosynthesis is important to these communities because of the symbiotic zooxanthellae of reef-building corals and the role of calcareous-secreting algae in sediment production. In our view, claims of high latitude fossil coral reefs may be based on records from continental plates with poor palaeomagnetic control, or from areas like Japan that have a long history of accretion of oceanic islands (Kobayashi 1999).

A concept of low-latitude atmospheric circulation and its effect on oceanic currents is essential in defining the tropics. The dual Hadley cells dominate this zone and somewhat beyond, with ascending limbs near the equator, providing much of the precipitation for the rainforests, and descending limbs in the subtropics, resulting in the desert zones and their associated evaporite deposits (Parrish 1998, p. 3). The Hadley cells are most consistent over the oceans where the latitude of the descending limbs averages $35^{\circ}$ in the summer and $30^{\circ}$ in the winter, while over land they are poleward and well developed only in the winter. Since the desert belts typically are quite wide, up to $20^{\circ}$ of latitude, they encroach on the tropics, and serve to divide floras and faunas of the tropics and the temperate zones. An exception to this is along the east-facing margins of continents, such as Middle America and China, where warm moisture-producing currents and onshore winds provide abundant rainfall.

The Hadley circulation has been a stable feature throughout the Phanerozoic, judging by a number of studies on the palaeolatitudes of evaporite deposits (Gordon 1975; Ziegler et al. 1981; Parrish et al. 1982). The Hadley cells are driven by the concentration of solar heating in lower latitudes, but the poleward limbs are determined by the Coriolis Effect (Barry \& Chorley 1998, p. 129). Thus, upper level winds moving away from the equator are deflected to the east by the rotation of the Earth and never reach latitudes much above $35^{\circ}$, where they descend, contribute to surface winds back toward the equator, and complete the cell. An interesting question is whether the Earth's more rapid rotational rates in the geological past (Kagan 1997) would have significantly affected the latitudinal limits of the Hadley cells. However, a general circulation model study has shown very little influence on latitudinal effects even for Precambrian rotation rates (Jenkins 1996) and Earth's rotation in the late Palaeozoic, the starting point of our study, was just $4 \%$ faster than today (Williams 1989).

\section{Approach used in this paper}

We begin this paper with present-day comparisons of peat bogs with rainforest patterns, of evaporite deposits with desert belts, and of reefs and carbonate deposits with temperature and ocean circulation patterns. We attempt to isolate the controlling factors for these tropical-type deposits and then to examine their patterns on 16 stage-length palaeogeographical maps ranging from the Early Permian to the Mid Miocene. The objective is to examine both the continuity and the variability of the tropics through nearly 300 million years, ranging from 'icehouse' to 'greenhouse' climates and back again. Palaeogeographical mapping for this time span is fairly well established, so that palaeolatitudinal determinations are probably accurate to about $5^{\circ}$. Deposits associated with small terranes or accretionary prisms have been left off the maps if their original position is uncertain.

The lithofacies data used in this paper were assembled from thousands of primary and secondary literature sources. An attempt was made to provide uniform coverage of the world for selected stagelength intervals, with an average duration of about six million years. The certainty with which a given formation can be assigned to the nearest stage is variable, but the rate at which plates move with respect to latitude is slow, so the data provide reasonably accurate 'snapshots' of the climate zones for each interval. The following climate indicators have been chosen to give the most comprehensive view of the tropical climate, although each is subject to specific biases. The coals of the past are biased toward the lowland depositional sites, while upland peats are well known from the present world and may occur on mountainsides in deserts if orographic precipitation occurs regularly. We include coals of tropical as well as temperate latitudes, but the difference is generally clear on the maps because the intervening desert zones provide a wide separation in most regions. The evaporites are less easy to correlate because they tend to be unfossiliferous and, again, there is a bias toward coastal settings in the geological record. Reefs are indicative of a tropical climate, but there is a problem with the reef data because carbonate build-ups tend to form at the outer margin of the continental shelves or on oceanic islands. The islands are typically trans- 
ported thousands of kilometres and subducted or incorporated in accretionary prisms, while the shelf margins subside and may escape notice unless penetrated by drilling, or brought to the surface tectonically. Perhaps fewer than $10 \%$ of fossil reefs have been sampled in the geological record, and some of the bestknown examples occur in mountain belts. Our carbonate data are limited to sections that contain more than $50 \%$ carbonate beds as integrated over the stage interval. Finally, the carbonate data for the two Permian intervals have not been assembled systematically, so this aspect of our coverage is not as representative as that of later times.

We compare the climate-sensitive sediment patterns with predictions made in general circulation model studies; these are available for some stages of each of the last six geological periods. The modelling studies range in style and completeness, but the maps that are useful to our study are listed, together with their references, in Appendix 1. Ideally, a climate model study should incorporate a fully coupled ocean circulation model because of the many feedbacks between atmosphere and ocean, but this is just becoming the state of the art, and most of the papers listed use a static ocean in their models. Also, a number of the model studies do not employ comparisons with geological data so, in effect, they have yet to be tested. One source of model/data mismatch can result from the input palaeogeography. Local effects such as mountain ranges can have a disproportionate effect on atmospheric circulation and palaeo-elevations of such features are difficult to determine. In general, the model output is seen to conform to the geological data and, when this test is passed, a more complete picture emerges.

Finally, we incorporate within the text information from fossil floras and faunas that reflect on the climate of the tropics and subtropics. Especially useful is a new summary on the evolution of tropical rainforests as deduced from palynology, and a review of macrofloras and climate-sensitive sediments (Morley 2000). Also, a major new summary of fossil reefs through time has just appeared and provides much information on the distribution, biotic structure and composition of carbonate build-ups (Kiessling et al. 2002). Additionally, we refer to studies that employ biogeographical distributions and diversity data to infer temperature gradients and tropical current systems. Particularly useful in this connection are worldwide treatments that include control points plotted on reconstructed basemaps, thus permitting latitudinal limits to be established. Ideally, quantitative treatments that integrate across the diverse marine phyla would be desirable, but these do not exist even for the Recent!

\section{The tropics today}

North-south trending continents and oceans uniquely divide the present-day world such that tropical floras and faunas are isolated in three terrestrial and two marine regions, the Pacific and Indian Oceans still being connected across shallow straits. The three rainforest floras are biogeographically distinct at the generic level (Morley 2000), reflecting geographical separation by wide oceans and/or broad deserts since the early Tertiary. Barriers to migration of marine organisms are much more recent; Pliocene in the case of the Isthmus of Panama (Coates et al. 1992; Pindell et al. 1988) and Late Miocene in the case of the Arabian Peninsula (Rogl \& Steininger 1984). In effect, the present world offers several examples of each of the terrestrial and marine tropics, while much of the $300 \mathrm{Ma}$ of the geological past covered in this paper had just one land area, Pangea, and one major ocean, Panthalassa, with a westward extension in the form of Tethys. The widths and configurations of the tropical landmasses and oceans are variable, and this is reflected in the impact of important atmospheric and oceanic effects such as precipitation, seasonality, temperature and upwelling. So, despite being atypical of the geological past in some ways, the present world affords examples of the various geographical configurations that have parallels in the past.

Many terrestrial climate classifications are available for the present, but the one that is most applicable to the past is Walter (1985). In this scheme the world is divided into just nine biomes based on the annual precipitation and temperature patterns determined from a survey of about 8,000 meteorological stations. The approach was duplicated using a digital database of 13,000 ground-based stations and tested with a satellite-derived vegetation index (Lottes \& Ziegler 1994). These parameters were framed in terms of the number of months that temperatures and precipitation were sufficient for plant growth, in keeping with Walter's methodology, and excellent comparisons were obtained. This biome scheme has been applied to the Permian (Ziegler 1990; Rees et al. 2002) and the Jurassic (Rees et al. 2000). The tropical biomes are defined on precipitation since temperature is sufficient for plant growth throughout the annual cycle. The evergreen tropical rainforest biome is essentially everwet with monthly precipitation exceeding $40 \mathrm{~mm}$ for more than 10 months each year, while the tropical deciduous forest or savanna biome ranges from 4 to 10 months of monthly rainfall in excess of $40 \mathrm{~mm}$ (Rees et al. 2002). The subtropical desert biome has less precipitation, of course, and may extend to less than $12^{\circ}$ latitude in the case of the Sahara and even to the 
equator in east Africa, so is quite relevant to a discussion of the tropical regions.

A parallel climate classification of marine environments has been developed, based on water mass characteristics (Ziegler et al. 1998). Four subdivisions are relevant to the tropics, and these are based on temperature, salinity and productivity parameters relevant to marine organisms. The 'average tropical' water mass category is by far the most extensive and is defined by temperatures of $20^{\circ} \mathrm{C}$ and above. The 'wet tropical' and 'dry subtropical' water mass subdivisions are based on salinities below $32 \%$ and above $37 \%$, respectively, and are mainly coastal effects reflective of adjacent continental climates. The distribution of these water masses is limited today, but suitable settings were much more abundant in the geological past when epeiric seas intruded into continental interiors. Finally, 'cool subtropical' water masses are due to upwelling and dominate along west-facing coasts, extending in some cases to within a few degrees of the equator. These currents impact the coastal climate because the cool conditions suppress evaporation as well as precipitation. The water mass boundaries may move during the seasons, but at any time may be quite distinct because of density differences due to thermohaline effects. This contrasts with continental climate boundaries, which are typically gradational and, therefore, more difficult to map.

\section{Controls on terrestrial biomes and sediments: wet climate settings}

Tropical rainforests contain the highest diversity communities on Earth, with 120 to 250 tree species in a local plot (0.1 hectare; Morley 2000, p. 14). The extent of the modern tropical rainforest, prior to human influence, has been determined by Collins (1990; Fig. 1 herein). There are three biogeographically distinct areas, listed in order of decreasing rainforest cover and diversity, namely South and Central America, southeast Asia through New Guinea, and central Africa (Morley 2000, p. 8). Thus, Africa, the largest tropical continent, is the least well endowed with this biome, probably because the moisture sources are restricted by the generally high elevations and vast expanse of the continent. In addition, the upwelling-induced desert associated with the Somalia Current (Ittekot et al. 1992) terminates the rainforest on the east. The rest of equatorial Africa is dominated by the Intertropical Convergence Zone (ITCZ), a belt of rainfall up to $2000 \mathrm{~km}$ wide that moves north and south with the seasons (Ziegler et al. 1987), and the rainforests simply depend on the seasonal overlap of the ITCZ where the precipitation is continuous through the annual cycle. Climate model results show wider latitudinal excursions of the ITCZ in the interval 6,000 to 11,000 years ago, during the phase of the Milankovitch cycle when northern hemisphere seasonality was enhanced (Kutzbach et al. 1998). This resulted in an expansion of the seasonally wet savanna zone at the expense of both the rainforests and the deserts. This model result has implications for the 'greenhouse' world when, we believe, seasonality was enhanced by the sheer size of the tropical landmass and when rainforests appear to have been rare or nonexistent.

The South American rainforests are the most extensive of all due to the low, basinal setting of the Amazon region and the concave-eastward Andean mountains that serve to stall the moisture-laden easterlies. The ITCZ dominates along the equator, but other important rain-producing systems include the orographic and the diurnal land-sea breeze systems that gain moisture from the warm currents along the east-facing coasts of Brazil and Central America (Gyllenhaal et al. 1991). So, while the rainforests associated with the ITCZ are restricted to within $10^{\circ}$ of the equator, the montane rainforests and coastal swamps range to $30^{\circ}$ south and nearly $25^{\circ}$ north. The same variety of precipitation systems is present in southeast Asia, but this is an ocean-dominated system with large islands and peninsulas ranging from India and South China to Java and northeast Australia. The great equatorial coal swamps of the late Palaeozoic, discussed later, must have shared much in common with this tectonic and geographical setting.

Coal deposits have been used as an indicator of rainforests of the past and while most present-day tropical peats fall within the mapped rainforests, the distribution of peat swamps within this biome is uneven (Fig. 1). This may reflect a sampling problem; peat has little value as a commodity in the tropics, and equatorial swamps are difficult and unpleasant places to work. Another problem is that the peats may have formed in mangrove swamps, which, by their nature, derive moisture from seawater, not rainfall. Indeed, mangroves extend into regions beyond the rainforests, occupying bays and river mouths along many tropical and subtropical coasts except in areas adjacent to cool upwelling currents (Tomlinson 1986, p. 41). Mangrove communities seem to be more luxuriant in humid climates where the nutrient supply is better (Kathiresan \& Bingham 2001) and mangrove peats are best developed in areas with the highest rainfall (Woodroffe 1992). So there may be an indirect association of mangrove peats with rainforests and high precipitation continuity. Tropical peats are best known in southeast Asia. In Africa they seem to be 

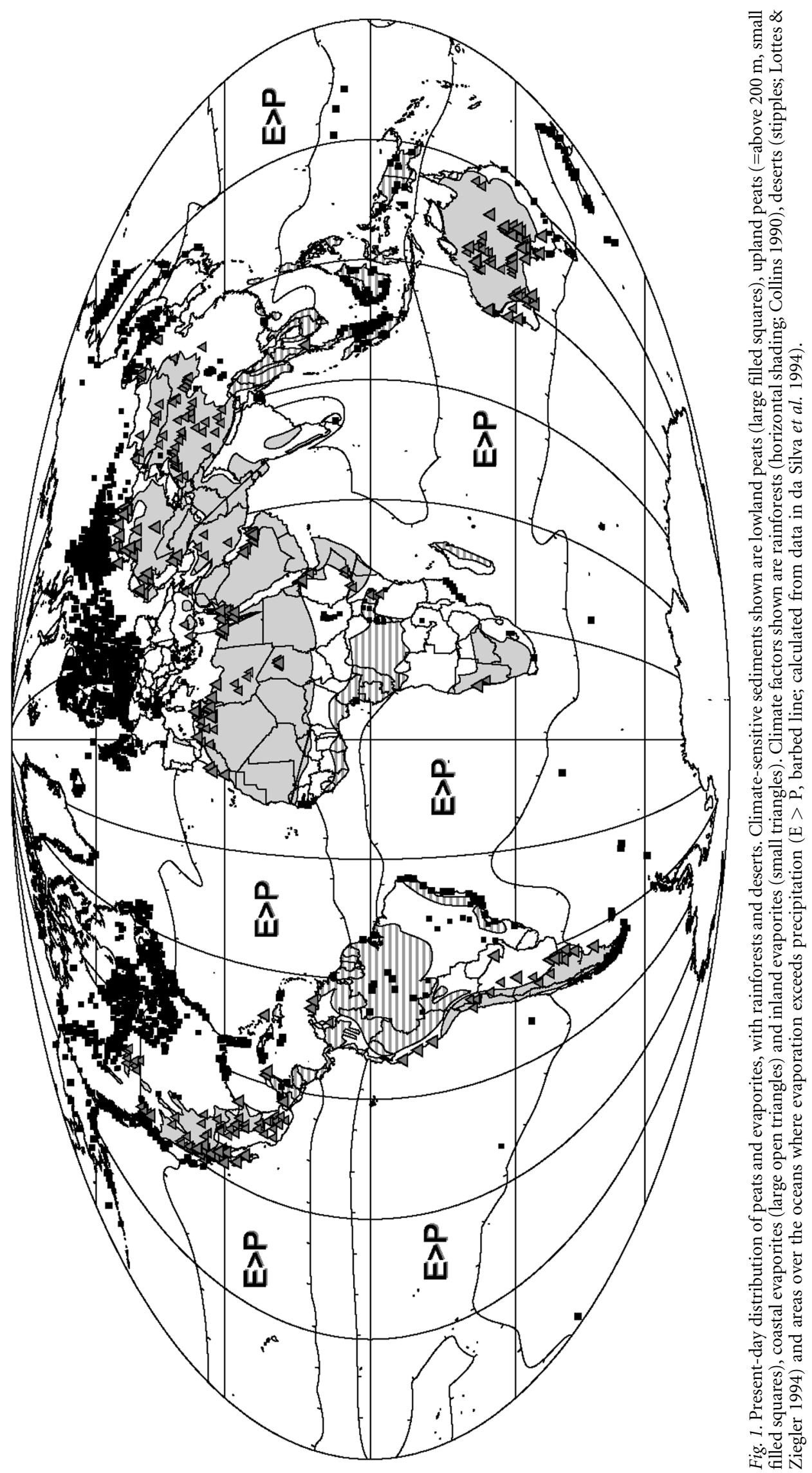
restricted to a few mangrove settings along either coast or to upland cloud forests of the east African rift shoulders (Lottes \& Ziegler 1994). One might expect the Amazon Basin to contain more peat, but here the river levels fluctuate up to $20 \mathrm{~m}$ on an annual basis, due to the asymmetry of the drainage network with respect to the Equator; the resulting alternate flooding and draining of the depressions is not favourable for organic accumulation or preservation (Ziegler et al. 1987).

\section{Controls on terrestrial biomes and sediments: dry climate settings}

The desert areas on our map (Fig. 1) are based simply on a lack of vegetation or, more precisely, as areas with detectable vegetation for two or fewer months a year, as determined by satellite measurements of the vegetation index (Lottes \& Ziegler 1994). It is difficult to specify the precipitation characteristics of deserts so defined, but the advantage of using the satellite data is that the shapes and positions of the deserts are accurately portrayed. The deserts of the world are due to one or more causes (Chandler 1994), the most important being the presence of subsiding or stabilized air masses associated with the descending limbs of the Hadley cells, a feature common to all the great subtropical continents. Second, continentality isolates interior regions from moisture sources; the best example of this is the great deserts of central Asia. Third, orography can present rain shadows on the lee sides of topographic relief; the Great Basin of western North America and the Patagonian Desert of Argentina serve as prime examples. Finally, coastal upwelling, especially along west-facing coasts, depresses evaporation and stabilizes air masses, reducing convective rainfall. In reality, two or more of these factors probably reinforce each other in many deserts and serve to expand the desert area. The effects of upwelling tend to be in the lowest latitude, while continentality and orographic effects are observed at higher latitudes, at least in today's world. Most of the inland evaporite deposits occur within the desert belts as defined, although it must be mentioned that due to erosion evaporites of the continental interiors are not as well represented in the geological record as their marine counterparts.

Also shown in Fig. 1 are the zones over the oceans where evaporation exceeds precipitation; this map was prepared by simply comparing data sets of these two parameters (da Silva et al. 1994). Theoretically the coastlines adjacent to areas of high evaporation would encompass the modern coastal evaporite deposits, although some of these coasts do not contain evaporites and still others include abundant peat deposits. The lack of evaporites where they might be expected is due, we believe, simply to the lack of broad continental shelves with low gradients and suitably restricted evaporating basins. Thus, the largest evaporite basin today is the Kara Bogaz Gulf on the east margin of the Caspian Sea (Valyashko, 1972) which is about $150 \mathrm{~km}$ across, while evaporite basins of the past may have had surface areas up to 25 times as great. Some authors have been tempted to regard geological periods with broad evaporite basins (e.g. the Permian or Triassic) as being exceptionally dry intervals, but this may be a bias imposed by the presence of epeiric seaways within subtropical latitudes.

The occurrence of peats within the high evaporation zone is observed along eastern seaboards like the United States and southeast Brazil, both areas of warm currents and high evaporation. In these regions, there is diurnal alternation of temperature regimes such that the land is warmer during the day and draws rain showers that result in coastal swamps. During the night the reverse is the case, but the net effect is for precipitation to exceed evaporation over land and vice versa. We point out that evaporites are forming in the Bahamas today concurrently with peats along the colatitudinal Florida Coast. Admittedly, the Bahamian lagoons are small, but in the past, with shelf zones up to $1,000 \mathrm{~km}$ wide, evaporites may have formed offshore while peats were deposited in coastal swamps, a situation that is known in the Jurassic-Cretaceous of Algeria (see below). So, we feel that the evaporation zones shown in Fig. 1, using simply the excess of evaporation over precipitation, are relevant to an understanding of evaporite deposits in the geological past. Of course, the freshening effects of surface runoff will be found along such coasts, but again, given wide shelves, evaporation should prevail in the outer shelf regions.

\section{Controls on marine biomes and sediments}

Coral reefs are the focus of attention in the marine tropics because they are the centres of maximum biotic diversity with 50 to 70 hermatypic coral genera across broad regions of the Indo-Pacific province; in contrast, Caribbean reefs typically have under 20 genera (Veron 1993; Fig. 2 herein). Some 34 hypotheses have been proposed over the years (Veron 1995), many of them involving dispersion or vicariance events, to account for modern coral distribution. Here we concentrate on factors that limit coral reef development, which include temperature, shallowwater habitat availability and light penetration to the sea floor. Temperature (Fraser \& Currie 1996) has always been popular because reefs seem to be limited 


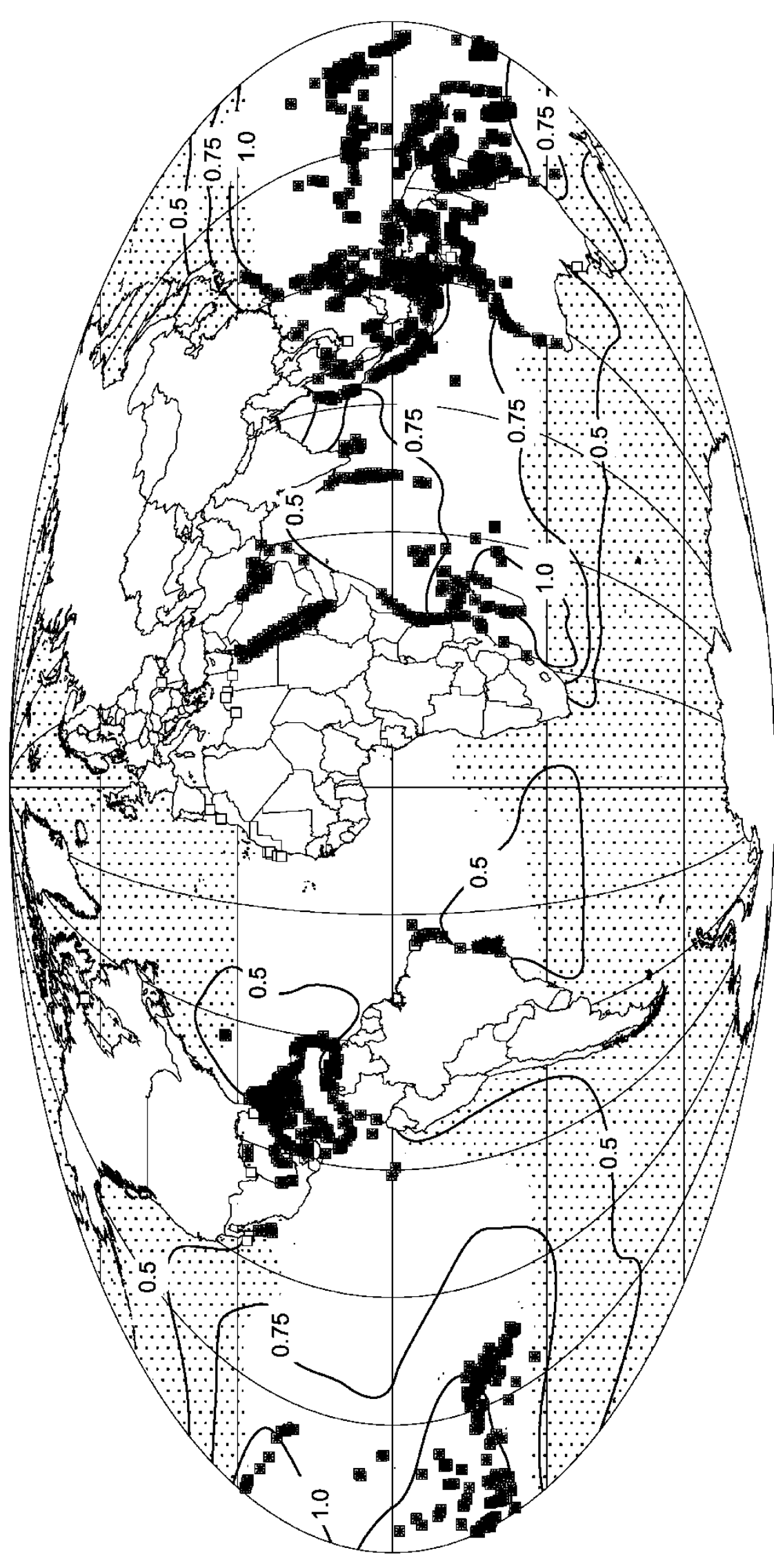

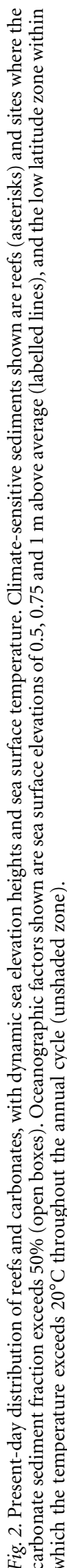


by the $18-20^{\circ} \mathrm{C}$ minimum isotherm and by the fact that calcium carbonate precipitation is enhanced by warmer temperatures. The problem with temperature as the only limiting factor is that many of the world's west-facing coasts are sufficiently warm, but devoid of reefs, so dispersal arguments are usually advanced to account for this shortcoming (Veron 1995). Shallowwater habitat shows a positive correlation with coral diversity (Bellwood \& Hughes 2001), but since the corals control their own habitat to a large extent, this argument has a circular element. Without coral growth, many Pacific atolls would subside below the photic zone, as a result of thermal contraction of the oceanic lithosphere. Light penetration to the bottom is a function of the zenith angle of the sun and the limits of light refraction to the sea floor, and this varies from a latitude of about $35^{\circ}$ in the winter to near the pole in the summer (Ziegler et al. 1984). Since corals are fixed to the bottom, they are limited to the latitudes where the potential for light refraction occurs throughout the annual cycle. Further limitations on light penetration are imposed by the clarity of the water, which is lacking in upwelling zones (due to high surface productivity) and in areas of high clastic runoff.

We maintain that the clarity of sea water is essential for coral growth because photosynthesis is critical in reef-building corals due to their symbiotic relationship with zooxanthellae and, also, in the productivity of calcareous-secreting algae that are important sediment producers in carbonate systems. New satellite-derived data sets are available to examine the ocean surface characteristics that correlate with reef growth. The Topex/Poseidon satellite (da Silva et al. 1994) has yielded data on dynamic sea surface height, which varies by just a few metres over the world's oceans. However, the upwelling zones are clearly marked as depressed zones along the eastern boundary currents, as are the mid-ocean upwelling systems, both along the equator and above $40^{\circ}$ in the higher latitudes. The intervening broadly elevated areas are centred at about $20^{\circ}$ north and south, and displaced toward the west sides of the oceans. Thus, they occupy the same latitudinal belts as the subtropical high-pressure zones and are ultimately related to the Hadley cells. The height of the bulge is proportional to the width of the ocean, so the Pacific's bulge is well over a metre above average and the Atlantic's is about half that value. These are the areas of downwelling; their shapes fit the distribution of the modern reefs very well (Fig. 2) and their heights correlate with the degree of coral diversity (Rosen 1988). Another useful satellitederived data set relates to the colour of the ocean as determined by the SeaWiFS Project (2002). This is a measure of surface productivity and demonstrates that the reefs are limited to areas of lowest chlorophyll concentration in the surface waters.

The strongest limiting factor for reefs and coral diversity may be upwelling, which brings cold nutrient-rich water to the surface, encouraging productivity in pelagic communities but suppressing the 'carbonate machine'. The surface water column productivity inhibits light passage and can also overwhelm the bottom with organic-rich mud capable of consuming the available oxygen in its decay. Ironically, the lowest latitudes have fewer reefs because of the dual effect of equatorial upwelling in some areas as well as the high rainfall and surface runoff from adjacent land along the ITCZ in other areas. In fact, Cretaceous reefs of the Pacific Plate became drowned sequentially in the order they were transported across the equator (Jenkyns \& Wilson 1999), due, we assume, to equatorial upwelling. Fortunately, past upwelling zones have been modelled by a number of workers (Appendix 1) and it is also possible to model dynamic sea surface height (Kim \& Crowley 2000).

In summary, the tropical continents and oceans vary in size and shape, and influence the local climate in various ways that may, in turn, be examined for clues to the impact of the atmospheric and oceanic circulation during the changing configurations of the geological past. In the following sections we examine the patterns of the climate-sensitive sediments through geological time from the Permian to the tertiary (Figs 3-10). We make reference to the most recent climate modelling studies and include ancillary information from fossil plant and animal distributions to expand the climate interpretations as they apply to the tropical and subtropical latitudes.

\section{The Permian tropics}

Permian palaeogeography represents an advanced stage in the formation of Pangea with the megacontinent spanning the tropics and extending to high northern and southern latitudes (Fig. 3; Ziegler et al. 1997). The near-equatorial Appalachian collision of northern and southern continents was completed within the Permian, while a number of south Asian microcontinents were moving northward through the tropics in Tethys. Pangea had a narrow 'waist', $5000 \mathrm{~km}$ wide at the equator, so the equatorial portion of the Panthalassan Ocean was $35,000 \mathrm{~km}$ wide, including the Tethys, which was partially enclosed by the south Asian microcontinents. The Tethyan margins have been subsequently deformed tectonically, so the exact configuration of the ocean is unknown, but most of it was between $40^{\circ}$ north and south. Most tropical faunas of the period were found within the 


\section{A. Sakmarian (281 Ma)}

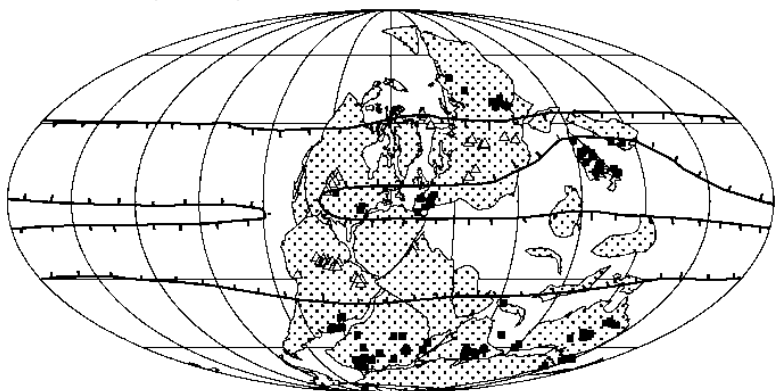

C. Induan (246 Ma)

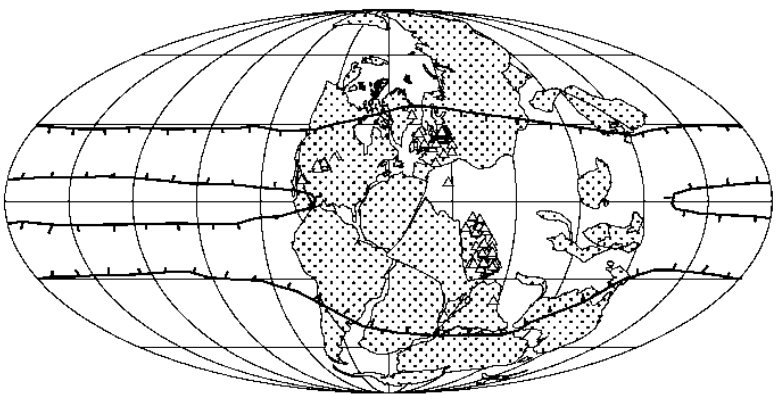

B. Wordian (265 Ma)

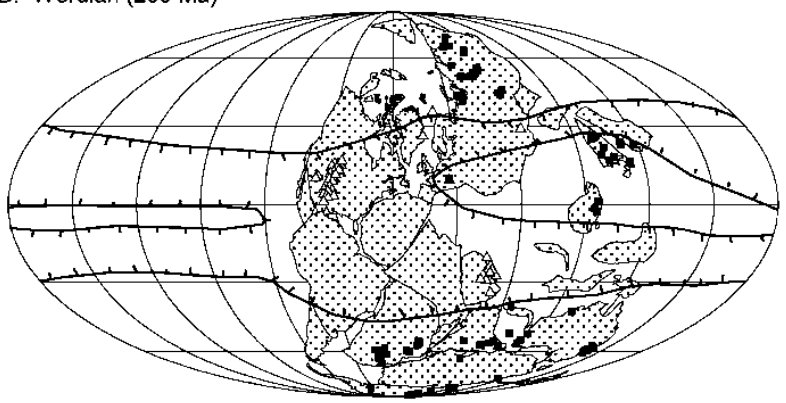

D. Norian (216 Ma)

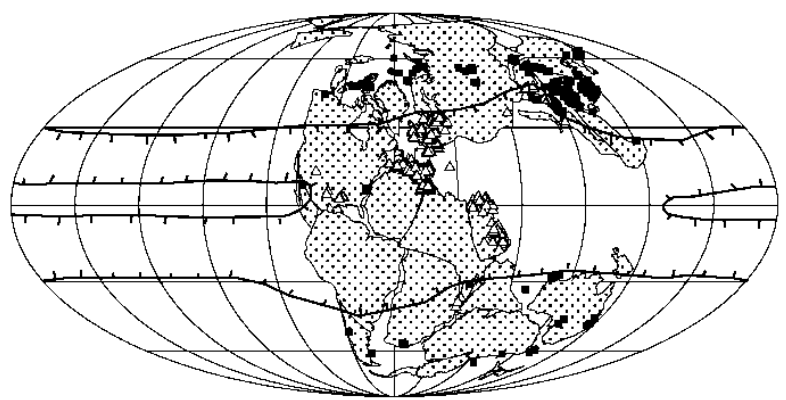

Fig. 3. Permian and Triassic coal (filled squares) and evaporite (triangles) distributions. Barbed lines enclose areas of high evaporation inferred from evaporite deposits and uniformitarian principles. $\square$ A. Early Permian. $\square$ B. Mid Permian. $\square$ C. Early Triassic. $\square$ D. Late Triassic.

A. Sakmarian $(281 \mathrm{Ma})$

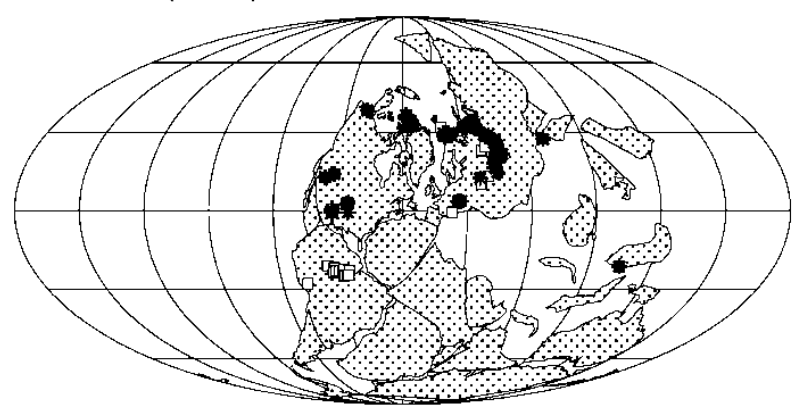

C. Induan (246 Ma)

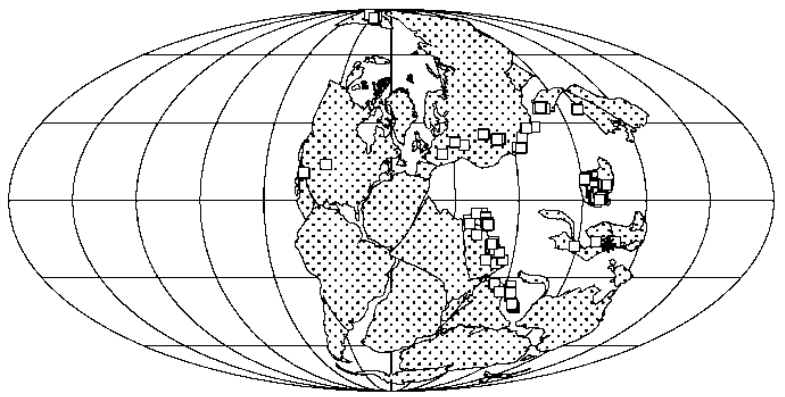

B. Wordian (265 Ma)

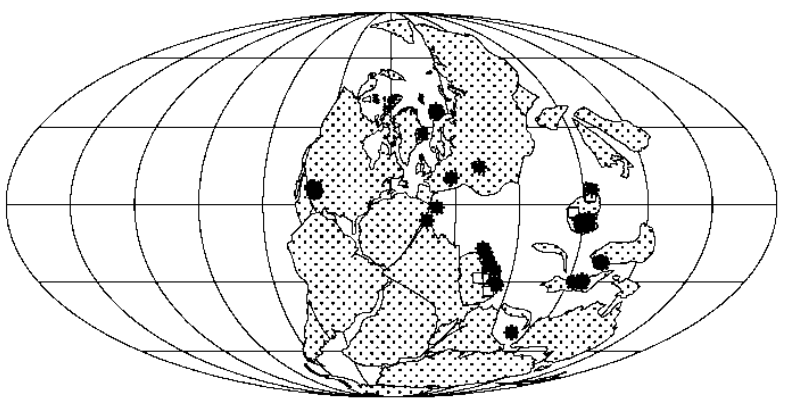

D. Norian (216 Ma)

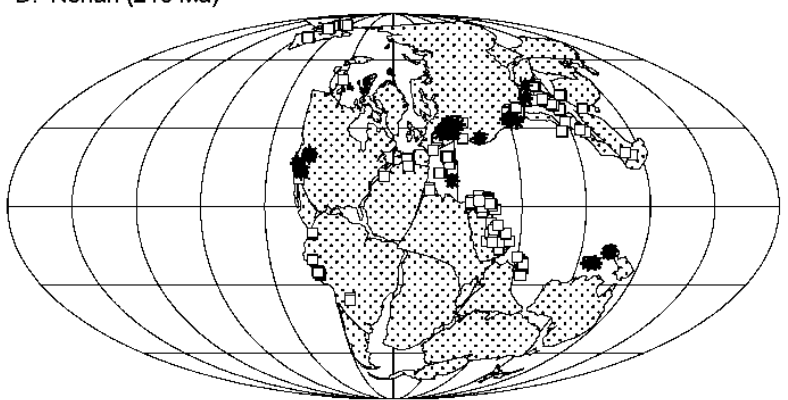

Fig. 4. Permian and Triassic reef (asterisks) and carbonate (open boxes) distributions. $\square$ A. Early Permian. $\square$ B. Mid Permian. $\square$ C. Early Triassic. $\square$ D. Late Triassic. 
A. Pliensbachian (193 Ma)

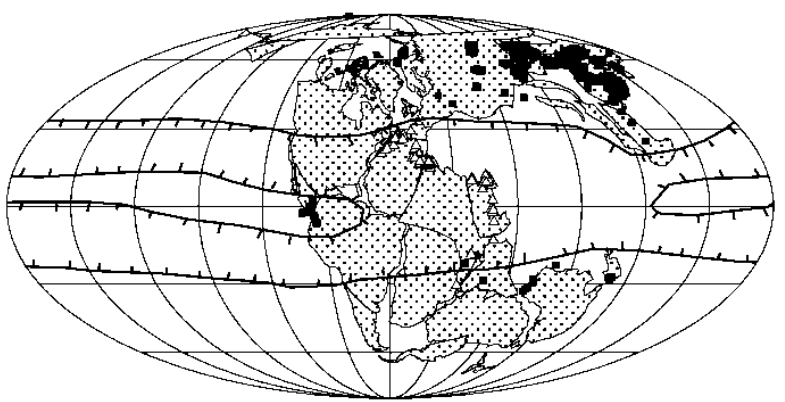

C. Tithonian (148 Ma)

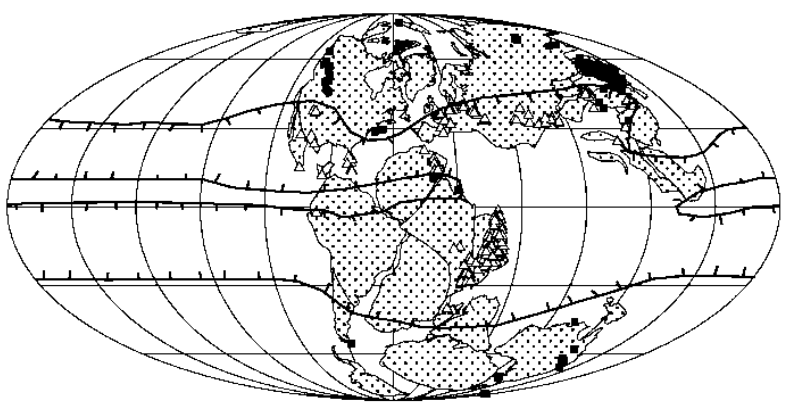

B. Callovian (162 Ma)

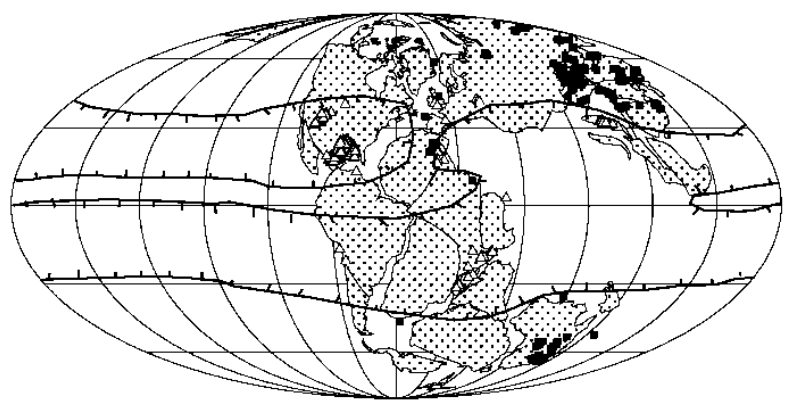

D. Valanginian (135 Ma)

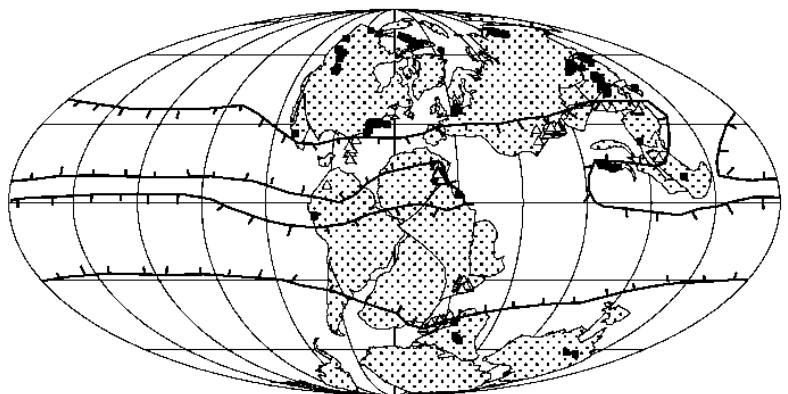

Fig. 5. Jurassic and Early Cretaceous coal (filled squares) and evaporite (open triangles) distributions. Barbed lines enclose areas of high evaporation inferred from evaporite deposits and uniformitarian principles. $\square$ A. Early Jurassic. $\square$ B. Mid Jurassic. $\square$ C. Late Jurassic. $\square$ D. Early Cretaceous.

A. Pliensbachian (193 Ma)

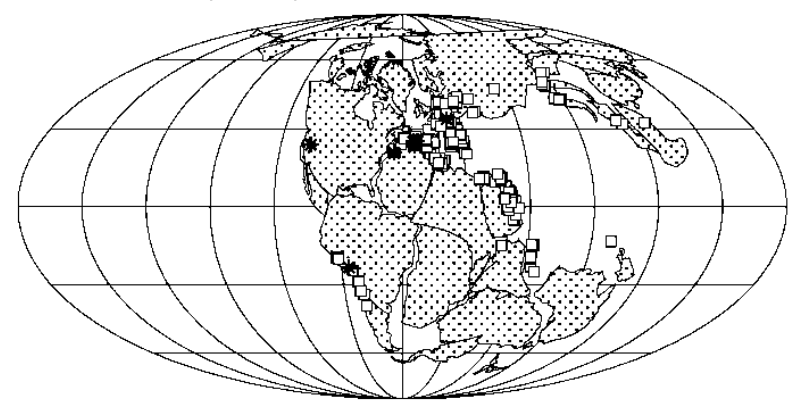

C. Tithonian (148 Ma)

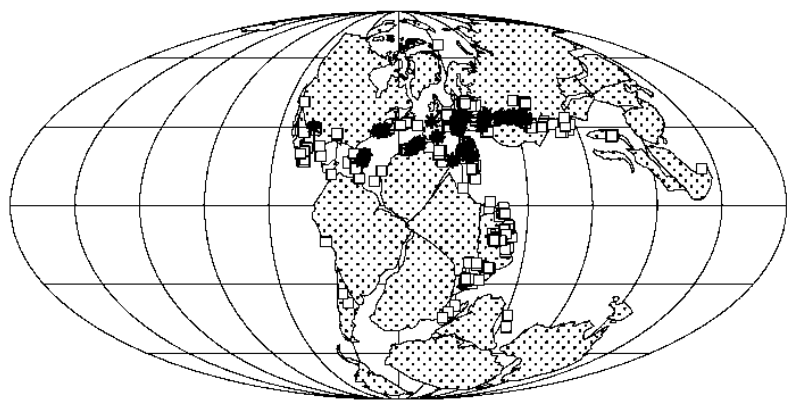

B. Callovian (162 Ma)

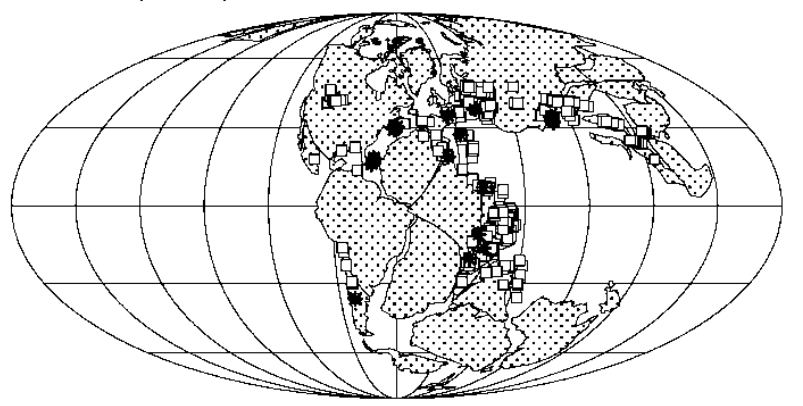

D. Valanginian (135 Ma)

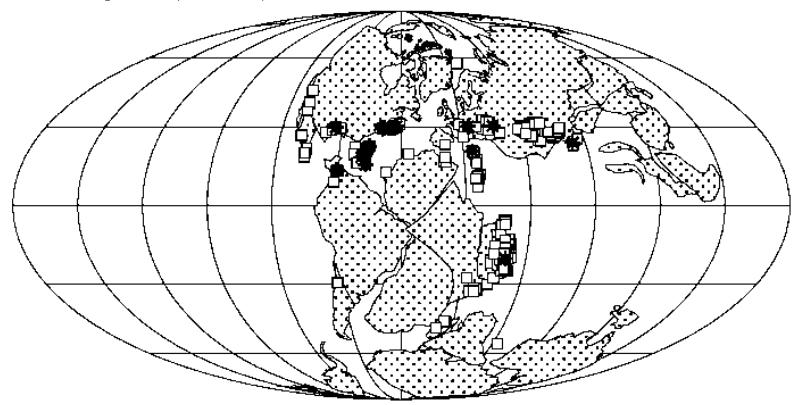

Fig. 6. Jurassic and Early Cretaceous reef (asterisks) and carbonate (open boxes) distributions. $\square$ A. Early Jurassic. $\square$ B. Mid Jurassic. $\square$ C. Late Jurassic. $\square$ D. Early Cretaceous. 
A. Aptian (117 Ma)

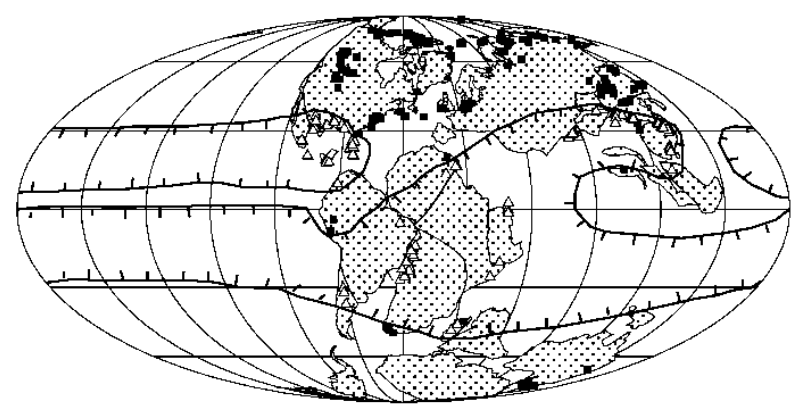

C. Coniacian ( $87 \mathrm{Ma})$

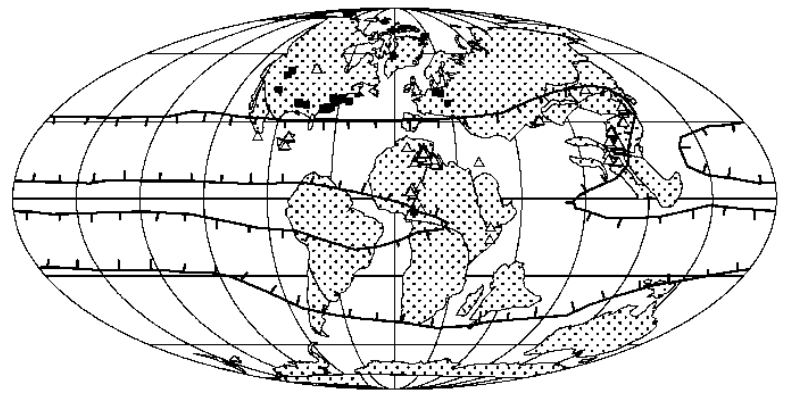

B. Cenomanian (96 Ma)

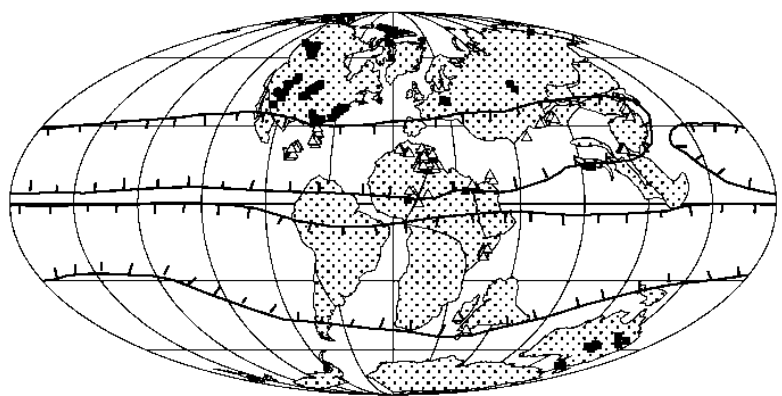

D. Maastrichtian (68 Ma)

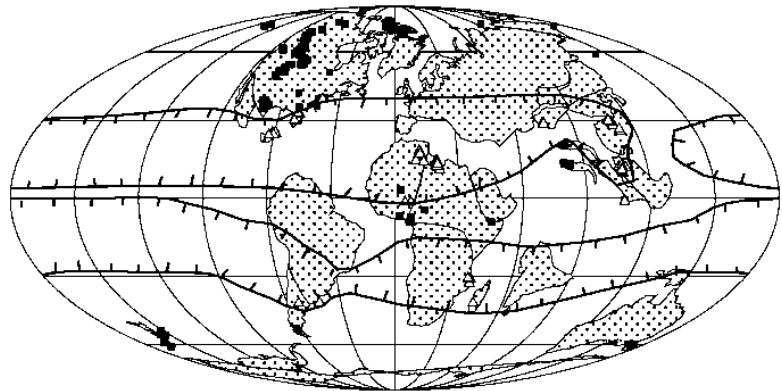

Fig. 7. Mid and Late Cretaceous coal (filled squares) and evaporite (open triangles) distributions. Barbed lines enclose areas of high evaporation inferred from evaporite deposits and uniformitarian principles. $\square$ A, B. Mid Cretaceous. $\square$ C, D. Late Cretaceous.

\section{A. Aptian (117 Ma)}

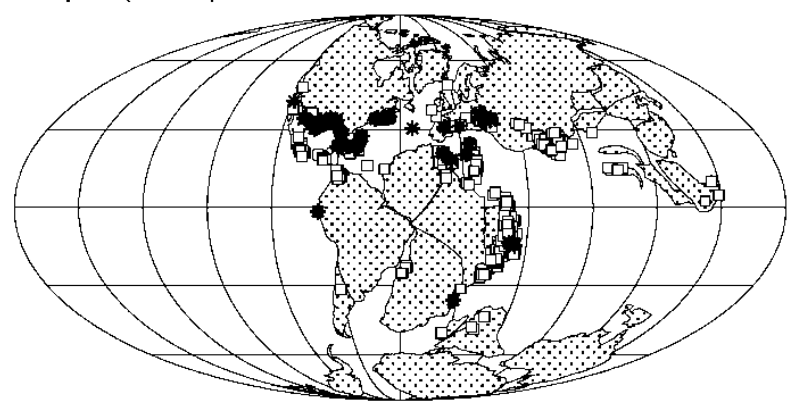

C. Coniacian (87 Ma)

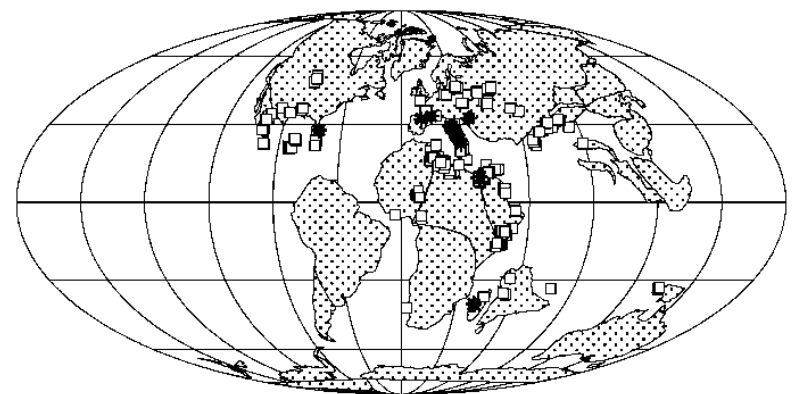

B. Cenomanian (96 Ma)

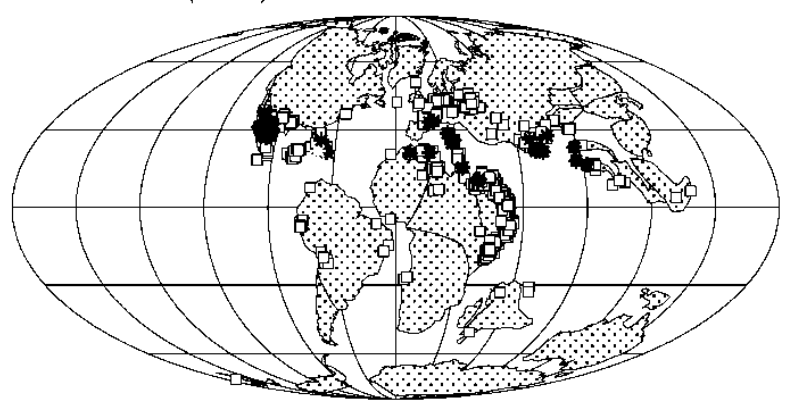

D. Maastrichtian (68 Ma)

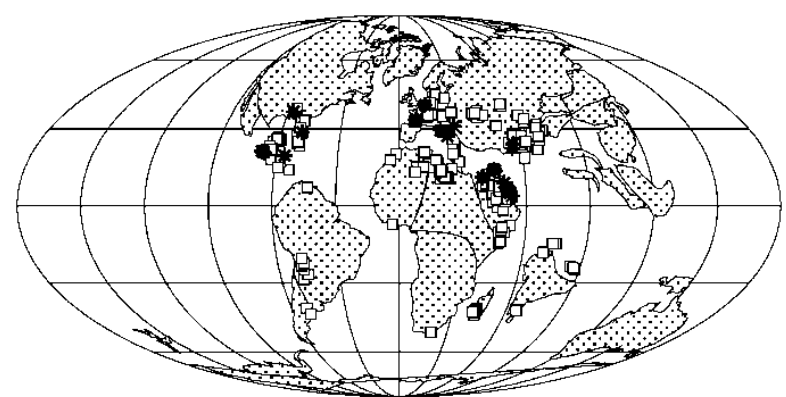

Fig. 8. Mid and Late Cretaceous reef (asterisks) and carbonate (open boxes) distributions. $\square$ A, B. Mid Cretaceous. $\square$ C, D. Late Cretaceous. 
A. Thanetian (56 Ma)

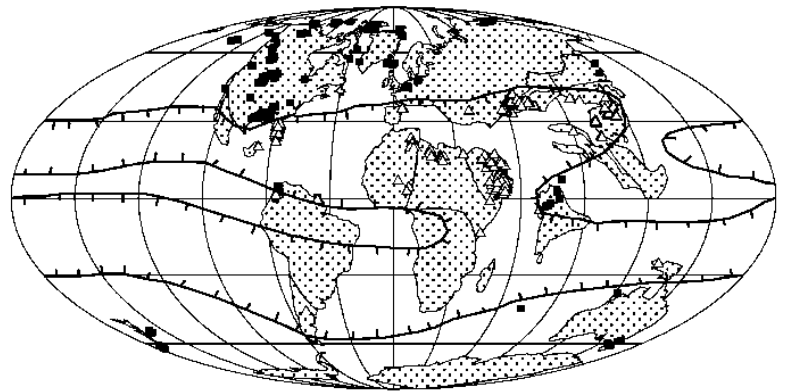

C. Chattian (26 Ma)

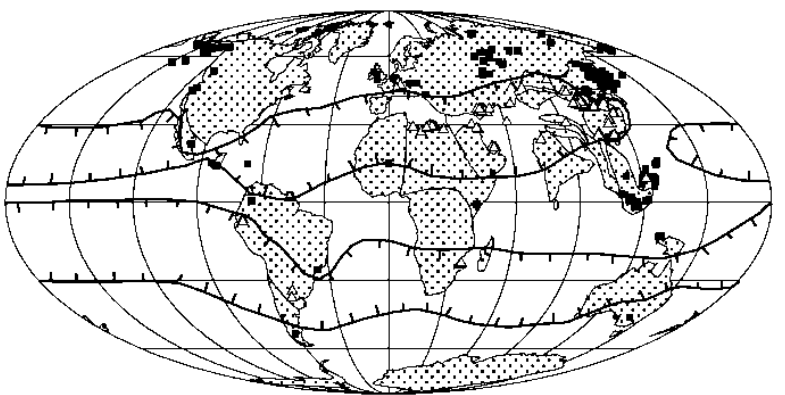

B. Lutetian (45 Ma)

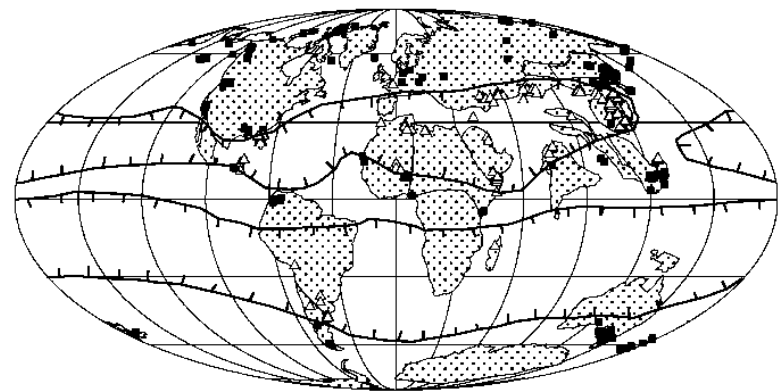

D. Serravallian-Langhian (15 Ma)

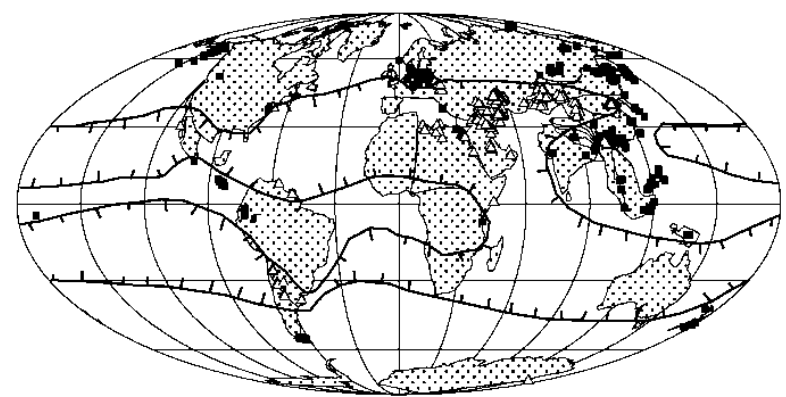

Fig. 9. Tertiary coal (filled squares) and evaporite (open triangles) distributions. Barbed lines enclose areas of high evaporation inferred from evaporite deposits and uniformitarian principles. $\square$ A. Paleocene. $\square$ B. Eocene. $\square$ C. Oligocene. $\square$ D. Miocene.

A. Thanetian ( $56 \mathrm{Ma})$

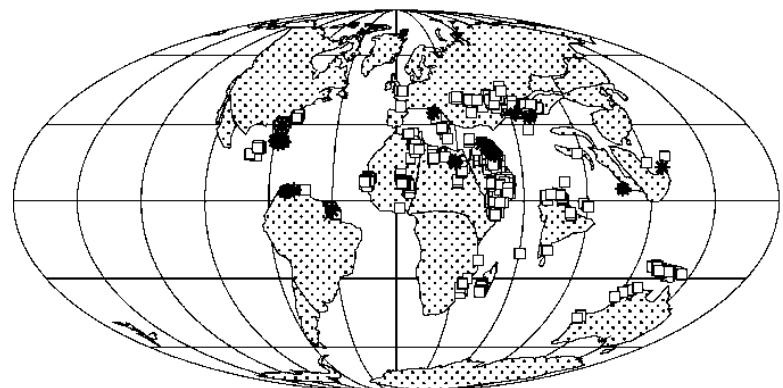

C. Chattian (26 Ma)

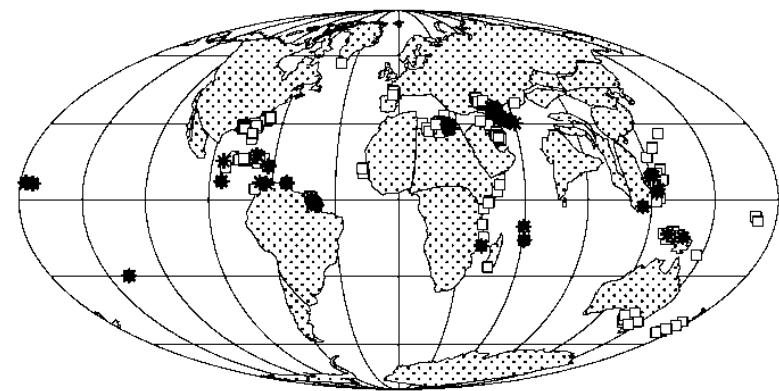

B. Lutetian (45 Ma)

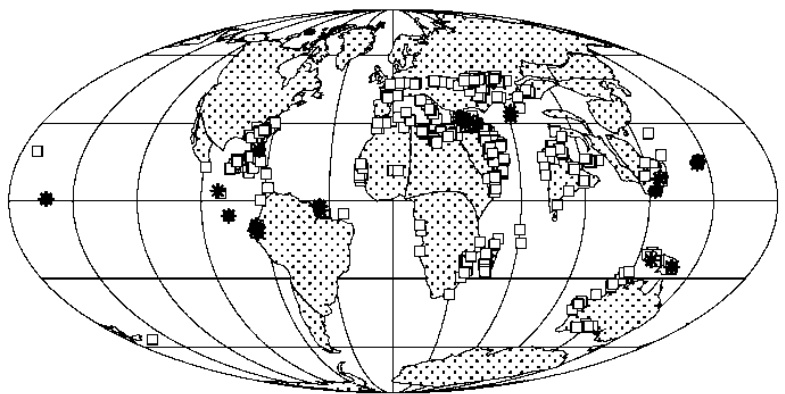

D. Serravallian-Langhian (15 Ma)

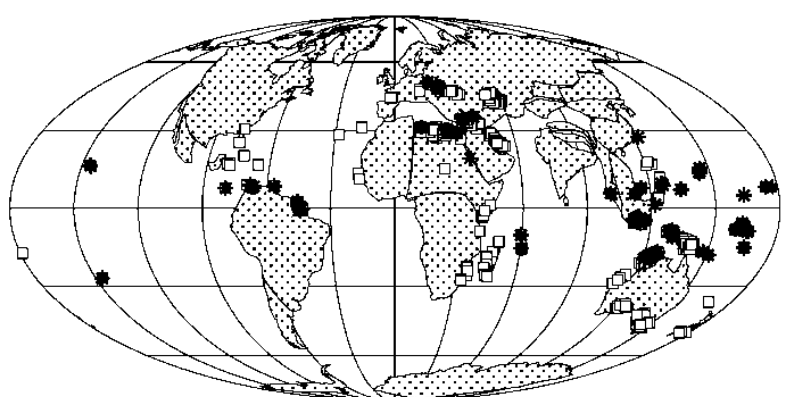

Fig. 10. Tertiary reef (asterisks) and carbonate (open boxes) distributions. Stages shown represent the Paleocene (A), Eocene (B), Oligocene (C) and Miocene (D). 
Tethys (Jin \& Shang 1997), which must have experienced warm currents, similar to the modern Gulf Stream, in view of its position along the eastern margin of Pangea. On the west side of Pangea, tropical faunas are confined to a narrow equatorial belt, extending from west Texas to Peru (Mei \& Henderson 2001), as might be expected from modern parallels. Another tropical marine area is observed along the margins of the Uralian foredeep, but connections to the Tethys were severed during the Early Permian and the area moved into the temperate zone (Ziegler et al. 1997).

A linked set of atmospheric and oceanic modelling studies has recently been completed for Early and Mid Permian time intervals. The atmospheric study (Gibbs et al. 2002) compared model precipitation with coal and evaporite deposits, and matched model wind directions with upwelling locations and aeolianite transport directions. The salient feature of Permian climate is the monsoonal circulation over Pangea leading to large seasonality and high aridity in the continental interiors. The model was also tested against floral distribution patterns based on over 100 sites around the world for each time interval (Rees et al. 2002). The model results were used to make biome prediction maps, based on the parameters controlling modern biomes (Walter 1985), and these were then compared with the biomes determined from the fossil record (Rees et al. 2000). Both model and data-based approaches indicate a well-developed Equator-to-Pole temperature gradient. The ocean modelling study (Winguth et al. 2002) includes a variety of maps, including temperature, salinity and upwelling for the Mid Permian interval. These parameters were used to generate an ocean water mass prediction map, which may be compared with the equivalent map reconstructed from climate-sensitive sediments (Ziegler et al. 1998). The salient feature of the tropical Permian oceans is the east-to-west asymmetry, with warmer currents extending to higher latitudes along the Tethyan Seaway margin of Pangea.

\section{Terrestrial biomes and sediments}

Contrasting climate patterns may be inferred over the tropical landmasses of the Permian based on fossil floras, coal deposits (Fig. 3) and model results. Pangea was dry and monsoonal while the North and South China microcontinents were perpetually wet with rainforests (Rees et al. 2002). This contrast developed during the Early Permian with the withdrawal of broad epeiric seas from the midcontinental U.S.A. and northern Europe. So, the moisture sources for the Carboniferous coal swamps were removed thousands of kilometres to the west and east, leaving savanna-like communities in the Permian (Ziegler et al. 2002). The Cathaysian province of south Asian regions became the locus of rainforest development and was associated with partially flooded microcontinents set in a warm Tethyan Sea, similar to the situation in southeast Asia today. We note that the coals of North China extend nearly to $30^{\circ}$ north and model results indicate that these should be regarded as deposits of the tropical rainforest (Rees et al. 2002).

Evaporite deposits are zonally distributed across Pangea and range up to $35^{\circ}$ north in the western U.S.A., Europe and the Russian Platform, and up to $35^{\circ}$ south in the Amazon and Arabian Basins. Most of these broad depositional basins seem to have had marine source waters, and they are set in deserts that must have played a significant role in differentiating terrestrial floras biogeographically into Angaran, Cathaysian and Gondwanan Realms (Ziegler 1990). We note that the Angaran and Gondwanan floras of the north and south temperate zones, respectively, are associated with coal deposits, so the evaporite belts serve to demarcate the tropical rainy zone from the temperate counterparts. The Permian is sometimes characterized as an exceptionally dry period because of the extensive evaporite deposits. However, the biome arrangement is similar to that of today and, in our view, the record is biased as a result of the fact that broad epeiric basins, particularly in Europe and the U.S.A., were situated in the subtropical latitudes.

\section{Marine biomes and sediments}

Reefs from selected stages of the Lower and Middle Permian are shown in Figure 4 while reef maps for all nine Permian stages are included in Ziegler et al. (1998). Excluded from these maps are reefs from accretionary zones, such as Japan and western North America, because the provenance of oceanic islands and smaller terranes is difficult to ascertain (but see Kobayashi 1999). Belasky (1994) used coral diversity patterns to estimate the location of some of the larger terranes on the assumption that Permian longitudinal diversity gradients were similar to those of today. His statistical approach would seemingly apply no matter what physical or biological models one might assume were in control. Even though the exact location of the terranes is unknown, we can say that island 'stepping stones' were available in the Pacific then, as today, for migrations of tropical species. Our maps show reef concentrations in northern Tethys in the Early Permian and southern Tethys in the Mid Permian, reflecting the gradual northward motion of Pangaea and hence the seaway, and the fact that cold air outflow of glaciers dominated the climate of the southern hemisphere in the Early Permian (Ziegler et 
al. 1997). Elsewhere, reefs were well developed in the western U.S.A., including the famous El Capitan reef of Texas, along a narrow equatorial zone during Early and Mid Permian times. Also, reefs lined the Uralian trough in the Early Permian before this basin moved to higher latitudes. Further details on reef distribution, composition and regional variation are included in Wahlman (2002) and Weidlich (2002).

A number of quantitative studies are available on the worldwide distributions of various marine invertebrates in the Permian, and these all show patterns relevant to the tropical water masses mentioned above. Belasky (1994) grouped lists of coral genera from throughout the Permian into Early and Late (retrospectively Mid) Permian. Latitudinal and longitudinal diversity gradients are apparent, with diversity centres in the South China platform sea, a pattern that is broadly similar to the present day. The corals occupy more sites than the reefs, but it should be mentioned that corals were not the major reef builders of the Permian (Wahlman 2002; Weidlich 2002). Fusulinid distributions parallel the corals, and, like the corals, were mainly restricted to the tropical carbonate platforms and probably had symbiotic algae (Ross 1995; Kobayashi 1999). Conodonts have been used to trace warm and cool water masses, and are not known from the polar zones (Mei \& Henderson 2001). Finally, brachiopods occur throughout the shelf regions of the world, but tropical provinces are well differentiated from the higher latitude faunas (Shi \& Archbold 1993; Jin \& Shang 1997). These biogeographical studies help to confirm that latitudinal temperature gradients were well established in the Permian, to judge by the number of provinces defined.

\section{The Triassic tropics}

Pangea moved about $10^{\circ}$ northward during the Triassic, a trend that continued the motion begun in the Permian, so that the landmass was symmetric with respect to the equator by the Late Triassic (Fig. 3). The Tethyan microcontinents also moved northward, but at a faster pace, and began to impact with northern Asia before the end of the period (Metcalfe 1994). By this time these Chinese and Indochinese elements formed the northern margin of the tropical seaway, but their interior regions experienced a transition to continental conditions, characterized by temperate zone floras and coals (Ziegler et al. 1996). Pangea was mostly assembled by the Late Triassic, when the initial rifts appeared that would evolve into the sea-floor spreading of the central Atlantic by the Mid Jurassic (Manspeizer 1994). Thus, the greatest level of continentality the Phan- erozoic world has seen was achieved in the Late Triassic. The Tethyan seaway was more latitudinally confined than in the Permian, reaching from about $30^{\circ}$ south to $30^{\circ}$ north, so it remained well within the tropics and subtropics.

A 'megamonsoonal' climate has been assumed for Pangea in view of the fact that land masses shaped like today's Eurasia are present in both the northern and southern hemispheres (Parrish 1993). A climate modelling study bears out this prediction, and includes experiments for the Early and Late Triassic (Wilson et al. 1994). Climate-sensitive sediments and various elements of the terrestrial fauna are included as a test of the model runs, and correlate reasonably well, with the exception of higher latitudes, where model annual temperature ranges were found to be too high. Winguth et al. (2002) showed, in an ocean model experiment for the Mid Permian, that warm currents would be deflected poleward by the Pangean configuration and would warm the polar regions by as much as $16^{\circ} \mathrm{C}$. We note that Pangea, from the Mid Permian through the Triassic, extended almost from pole to pole, but the same is true of the Panthalassan Ocean, while in today's world oceanic heat transport is effectively limited to lower latitudes because of the presence of landmasses at polar latitudes. We conclude that it is essential to employ fully coupled ocean-atmosphere models to attain sufficient heat transport to high latitude settings. An evaporite basin model has been developed for the Triassic and tested with the present-day geography (Pollard \& Schulz 1994). It is driven by the general circulation model of Wilson et al. (1994) and the familiar bimodal dry zones, representing the descending limbs of the Hadley Cells, are apparent in the two Triassic simulations. However, the western equatorial Tethys is also indicated as dry and this is generally confirmed by evaporite deposits, although improvements in the palaeogeographic maps would probably serve to increase the fit of the data to the model results.

\section{Terrestrial biomes and sediments}

There is a 'coal gap' in the Early to early Mid Triassic (Retallack et al. 1996), so that the great coal swamps of the tropical and temperate zones of the Permian disappeared at or about the end of the period. The timing and synchroneity of this event are questionable unless it can be established that a worldwide extinction was responsible for the coal gap. Rees (2002) has argued that the extinction of the peat-forming plants could have been due to regional effects, such as the passage of the Cathaysian basins out of the tropical rainy belt. The floras of these areas show an obvious and gradual transition to more xerophytic forms, and 
become similar to their European co-latitudinal contemporaries (Wang 1993). By the Late Triassic, coals were abundant in the temperate zones, but rare along the equator (Fig. 3). Of course, one would not expect tropical coal swamps if the only available lowlatitude land area was subject to the megamonsoon. One coal site that is near the palaeo-equator is located in the southeastern U.S.A. It formed in one of the rift basins that can be traced into eastern Canada and Greenland, and which have counterparts in northeast Africa and western Europe. These basins continue north to the temperate zone, and contain evaporites, playa deposits and aeolianites in the zone from $10^{\circ}$ to $30^{\circ} \mathrm{N}$ (Olsen \& Kent 2000). The coals near the equator must have derived their precipitation from the ITCZ, but there is insufficient evidence for the rainforest biome at this time. Also near the equator, but on the opposite side of Pangea, coals occur in marginal marine deposits of northwest Mexico (Zambrano Garcia \& Weber 1985). The relatively diverse flora from these deposits could represent a rainforest and its presence here is consistent with the general circulation model prediction (Wilson et al. 1994), that precipitation is present during extremes of the annual cycle. In other words, the effect of the monsoon is minimal here, but the latitudinal swings of the ITCZ increase progressively toward the east, especially over the Tethys. Also, cold upwelling conditions would be expected north and south of Mexico, and the cool air masses associated with these would help to dampen the seasonal excursion of the ITCZ along the western margin of the continent.

Triassic evaporites are extensive in the western U.S.A., northeast Africa and Europe in the northern hemisphere, and the Arabian Peninsula and Madagascar in the southern hemisphere (Fig. 3). The evaporites form a broad belt around the western margin of Tethys, and are nearly continuous from $30^{\circ}$ or $40^{\circ}$ north and south depending on the time interval considered. The aridity of this trans-equatorial belt is reinforced by the vegetation as reconstructed from the palynology (Visscher \& van der Zwan 1981). The traditional explanation is that the monsoonal winds blew parallel with the coast, without any onshore component, a situation pertaining to Somalia today. The evaporite basin model achieves good results for the Late Triassic, but fails in the case of the Early Triassic; we agree that the model would benefit by better small-scale topography and an ocean dynamics system (Pollard \& Schulz 1994). For descriptions of the sediments and biota that have been used to reconstruct the seasonal climates of the continental interiors, see Dubiel et al. (1991) for the western United States, and Holz \& Scherer (2000) for Brazil and other Gondwanan sections.

\section{Marine biomes and sediments}

There is a 'reef gap' in the Early Triassic, in parallel with the coal gap of the terrestrial realm. Early Triassic build-ups are limited to domal and planar stromatolites, and thrombolite beds under $20 \mathrm{~m}$ thick (Flügel 2002) and are not included on our map (Fig. 4). However, carbonate environments were present in the Early Triassic Tethyan and western American tropical and subtropical shelf regions. Reefs increased in numbers, size, diversity and latitudinal range from the Mid to Late Triassic, when they occurred throughout Tethys, and along the west coasts of North and South America (Flügel 2002). The high latitude carbonates on our Late Triassic map were associated with the Omolon Terrane and probably represent a condensed sequence formed in the absence of clastic sediment dilution. This terrane has moved relative to Siberia, but the amount is probably relatively minor (Ziegler et al. 1997).

Biogeographical studies centred on Tethys may be used to trace ocean currents and their influence on the tropical invertebrates. Yin (1985), working with Early Triassic bivalves, found a latitudinal diversity gradient with a central axis along the equatorial zone, from the Alps to South China, and a well-developed provinciality reflecting tropical Tethyan affinities with transitional and cool water conditions in either hemisphere. Tollmann \& Kristan-Tollmann (1985) stressed the similarities between the Tethyan and western North American tropical crinoids and foraminiferans of the Late Triassic, and theorized that equatorial easterly currents might have transported larvae of American forms toward Tethys. They also mentioned the role of 'suspect terranes' in providing island stepping stones to facilitate faunal and floral dispersal.

\section{The Jurassic tropics}

The rifting of Pangea began during the Jurassic with the opening of two northeast-trending oceans, the central Atlantic and the west Indian oceans (Figs 5, 6). The three continental plates that resulted included the combined North America and Eurasia, which rotated clockwise during the Jurassic until the south coast was roughly parallel with the $30^{\circ}$ line (Rees et al. 2000), where it remained through the Cretaceous. During the rotation, temperate coals replaced the subtropical evaporites of the western U.S.A., while the reverse succession is observed in China. This is the effect of continental motions and not climate change, as some have interpreted. Between the two opening oceans, the combined African and South American continents occupied the tropics, with the widest portion spanning about $7,000 \mathrm{~km}$ along the equator, and the southern 
portion extending into the temperate zone. The other Gondwanan elements, mainly India, Madagascar, Australia and Antarctica, moved on a southward trajectory into the temperate zone where they remained through most of the Cretaceous. Tethys continued as a tropical ocean as defined by its northern and western shorelines, but it was less confined on the south because of the widening Indian Ocean.

A number of climate modelling studies are available for the Jurassic (Appendix 1). A simulation of Early Jurassic climate, representing the late Pangean configuration, showed a wide monsoonal swing of the ITCZ over the eastern portion of Africa and the Tethys (Chandler et al. 1992). Climate-sensitive sediments were used as a test in this study and good agreement was found, especially with the dominantly temperate latitude occurrence of coals. The Late Jurassic world experienced higher sea levels as well as opening oceans and has been modelled by a number of research teams. The Chevron group in California compared their model results with climate-sensitive sediments as well as ammonite and dinosaur distributions (Moore et al. 1992; Ross et al. 1992; Moore \& Ross 1994). As might be expected, monsoonal effects were found to be reduced, but were still important over eastern Africa and eastern Asia. The Chevron group determined that the dinosaurs occur mainly in areas of limited precipitation associated with subtropical bands in both hemispheres. They also tested known ammonite distributions with predicted water mass variations in such factors as temperature and upwelling.

Other Late Jurassic climate model studies have been used to derive biome prediction maps for comparison with extensive data sets of fossil plant distributions (Rees et al. 2000). The floral data show highest diversities in the temperate zones, while the tropics are sparsely represented in the floral record; the model results suggest that this is due to the higher seasonality of precipitation in the tropics. Finally, a new study modelling vegetation and its influence on the carbon cycle is available and employs climate models of a number of time periods, including the Late Jurassic (Beerling \& Woodward 2001). Several types of maps were presented, including 'net primary productivity', but the ones we will use in the following section to compare with the fossil and coal data are the 'plant functional types' and the 'soil carbon concentration' maps, respectively.

\section{Terrestrial biomes and sediments}

Early to Mid Jurassic equatorial coal (Fig. 5) is known from southern Mexico and adjacent parts of Central America (Kottlowski et al. 1978). The rocks have been tectonized and the full-time range of the deposits is uncertain, but Middle Jurassic floras have been obtained there (e.g. Person \& Delevoryas 1982). We take the presence of coal to indicate everwet conditions, so this region may be a rare example of a Jurassic tropical rainforest. The setting along the western margin of Pangea is similar to the Late Triassic example mentioned earlier, except that it is about $1000 \mathrm{~km}$ to the south. Actually, the continent moved north while the rainy climates remained near the equator, which fits with the Early Jurassic climate model study of Chandler et al. (1992). Synchronous with the opening of the central Atlantic in the Mid Jurassic, coals appeared in Algeria and these fall within a narrow zone of predicted peats that extends from the palaeo-equator in Colombia, east-northeast to Algeria (Sellwood et al. 2000). Beerling \& Woodward (2001, p. 173) used their climate modelling study to infer a zone of 'evergreen broad-leaved' vegetation along this trend. Much of the Jurassic of Algeria is in the subsurface and little is known of the vegetation that formed the coal swamps. However, in Colombia a moderately diverse flora containing ferns, cycads and other elements has been recovered from carbonaceous sedimentary rocks (Lemoigne 1984). Southeast of the Algerian coal basin, the Mid to Late Jurassic climate has been interpreted as humid, but with a seasonal cycle based on scattered fossil remains, paleosols and sedimentary structures (Lefranc \& Guiraud 1990; Busson \& Cornée 1991; Barale et al. 1998). Elsewhere in the world, everwet climates are implied for southeast Asia by coals and model results (Beerling \& Woodward 2001, p. 173); this is the one portion of the Asian landmass that was moving into the tropics.

Evaporites become increasingly widespread in the Jurassic, ranging from $30^{\circ}$ north and south in the Early Jurassic to $40^{\circ}$ north and south by the Late Jurassic. This, we believe, reflects the general transgression of the sea, and the increase in depositional sites in the form of opening oceans and widening continental shelves, rather than an increase in aridity. The tectonic and eustatic changes apparently influenced the climate to become milder and more maritime, as landmasses became smaller and subdivided by epeiric seaways. It should be noted that evaporites occur seaward of, and even interbedded with, the coals of the Algerian basin (Busson 1970) and this transition is nearly $1,000 \mathrm{~km}$ wide, implying extremely low topographic gradients. Also implied are steady onshore easterly winds so that the moisture would be constantly evaporated over water and deposited over land, and such a prediction is contained in the modelling work (Moore et al. 1992). Another possible explanation for the interbedding of the wet and dry climate indicators is Milankovitch level fluctuations, which would modu- 
late the relative seasonality of the precipitation (Olsen \& Kent 2000).

\section{Marine biomes and sediments}

Jurassic reefs were confined to $35^{\circ}$ north and south, and shallow-water carbonates extended to slightly higher latitudes; these limits are similar to those found today (Fig. 6). Unlike today, carbonates are found on the west side of the Americas extending to latitudes generally occupied by upwelling currents. The explanation may be that the seas transgressed well onto the continent in the case of the Sundance Sea of western U.S.A. or the Neuquén Basin of Argentina and were isolated from open ocean effects. The number of reefs increased during the Jurassic due to the new sites generated by the opening of the central Atlantic corridor, which directly connected the Tethys with the tropical east Pacific. This expansion was paralleled by an increase in generic diversity and in reef type (Leinfelder et al. 2002).

The water masses for the Late Jurassic have been reconstructed (Ross et al. 1992) using a provincial level analysis of 47 ammonoid localities and the results of a climate model study. These authors inferred that boreal faunas were separated from Tethyan faunas by the $20^{\circ} \mathrm{C}$ isotherm, while ammonoids seem to be absent altogether in broad equatorial shelves extending from Arabia to southeast Asia, implying that there was an upper limit to the temperatures they could tolerate, perhaps $30^{\circ} \mathrm{C}$. Cecca (1999) agreed that temperature was important, but concluded that the absence of ammonoids from the equatorial areas was simply due to the very shallow nature of the shelves and stressed that ammonoid diversity is generally much higher in 'pelagic settings'. Ross et al. (1992) modelled upwelling zones for alternate seasons and showed that the majority of ammonoid localities fall in water masses with year-round upwelling currents, implying that surface productivity was generating their food resources.

\section{The Cretaceous tropics}

The palaeogeographic changes affecting the tropics during the Cretaceous involved mainly Africa and South America, which began drifting apart in the Early Cretaceous (Figs 5-8). However, the South Atlantic apparently did not become a significant moisture source or a barrier to dispersal until late in the Cretaceous. During this transition, South America remained in approximately the same orientation while Africa rotated counter-clockwise to the north. The northern continents occupied the same latitudinal zone as in the Late Jurassic with their southern margin in the subtropics. Tethys, with its extension through the widening central Atlantic and Caribbean, was basically centred over the north tropical zone with a constriction between northwest Africa and the Iberian Peninsula. The remaining Gondwanan elements began rifting during the Early Cretaceous. The only continent crossing the south tropic was India, which had begun its northward excursion. The coverage of epeiric seas increased during the Cretaceous with channels across Africa and South America in the tropics, while the boreal ocean was connected to the Tethys across North America, Europe and west Siberia (Ziegler \& Rowley 1998). By these mechanisms, the palaeogeography was transformed into a world of small landmasses and widening seaways. Predictably, this maritime world would have had progressively dampened seasonality in terms of temperature and precipitation.

The Cretaceous has been a favourite target for climate modellers and only the more recent studies will be reviewed here. The main challenge has been to explain the equable temperatures at high latitudes indicated by fossil floras (Herman \& Spicer, 1996). Valdes et al. (1996) used mid Cretaceous maps with, and without, the epeiric Hudson Seaway across North America and found temperature increases of $16^{\circ} \mathrm{C}$ or more with the greater sea coverage. Temperature comparisons were also made between studies using different models, but with similar palaeogeographies. Considerable differences were found, leading the authors to conclude that more tests with the geological record are needed. Another test of marine boundary forcing compared two intervals within the midCretaceous, and found that increasing the size of the Western Interior Seaway and the central Atlantic led to a reduction of the equator-to-pole temperature gradient by as much as $15^{\circ} \mathrm{C}$. A mid Cretaceous study with an oceanic focus is also available which uses a 'Parallel Ocean Climate Model' (Poulsen et al. 2001), one of a new generation of coupled atmosphere/ocean models. This study examined the effect of the opening South Atlantic and concluded that the relatively stagnant central Atlantic was progressively ventilated by thermohaline circulation influences from the southern hemisphere. A coupled atmosphere-ocean model has also been applied to the Late Cretaceous (Bush \& Philander 1997), although this study is flawed by the fact that the coastline was mistakenly shown at the shelf margin, so the epeiric seaways, which were especially extensive at that time, were ignored.

A number of vegetation modelling studies, based on general circulation model output, are available for the Cretaceous. Upchurch et al. (1999) and DeConto et al. (1999) addressed the question of the effect of vegeta- 
tion on the Late Cretaceous climate. They showed that the forests of the high latitudes reduced the albedo and insulated the land surface, and so had a significant effect on warming continental interiors and decreasing the equator-to-pole gradient. Of course, forests do not occupy the high latitudes today, so these studies help to understand polar warmth in the past. The Upchurch et al. (1999) study compared the model output with a fossil plant database and presented combined biome interpretations for the whole world, while vegetation modelling for both Mid and Late Cretaceous intervals were presented in Beerling \& Woodward (2001). Their model estimate of tropical rainforest coverage is wider than shown in the Late Cretaceous map of Upchurch et al. (1999).

\section{Terrestrial biomes and sediments}

Early Cretaceous coals are known from the palaeoequatorial zone of Peru (Figs 5, 7; Kottlowski et al. 1978) and presumably may represent the continuation of the west coast everwet zone of the Late Triassic through Mid Jurassic of Middle America. Also inherited from the Jurassic are the coals of Algeria, while the low-latitude everwet zone modelled for the Jurassic of Malaya and Tibet is represented by coal in the Early Cretaceous in a similar geographical setting. By the mid Cretaceous, dry or savanna-like vegetation has been interpreted across the tropics of Africa and South America, based on an impressive palynological sampling array (Dino et al. 1999). Support for an increase in aridity, with pronounced seasonality in rainfall, comes from reviews of the sediments, soils and megafossils of the Saharan region (Lefranc \& Guiraud 1990; Busson \& Cornée 1991). The vertebrate fauna included huge sauropods and crocodilians (Sereno et al. 1999, 2001; Benton et al. 2000), indicating open ground and a certain level of plant productivity, as well as continuously flowing rivers. A few low-latitude peats are known in the midCretaceous of equatorial Africa, but in view of the many depositional sites along the Trans-Saharan seaway it seems likely that these represent local mangrove-type swamps rather than tropical rainforests. The factors driving the increased aridity probably include Africa rotating so that its maximum width was along the equator by the mid Cretaceous. In our view this would have caused wide excursions of the ITCZ and a lack of concentrated rainfall (Ziegler $e t$ al. 1987). Also important is the fact that upwelling developed along the coast of Colombia and Venezuela throughout the mid Cretaceous to well into the Late Cretaceous (Vergara 1997; Villamil et al. 1999), which would have inhibited precipitation in this area. Beerling \& Woodward (2001) modelled evergreen forests in northwest South America and East Africa in the mid Cretaceous, but even this limited extent seems doubtful. The modern rainforests originated during the Late Cretaceous in a narrow equatorial band through Colombia, Nigeria and Somalia, to judge by the palynological record (Morley 2000, pp. 91-92). The data/model study of Upchurch et al. (1999) provides the best biome map of the tropics.

Evaporite beds are widely distributed throughout the tropics and subtropics during the Cretaceous (Figs $5,7)$. This was due to the broad shelf and epeiric sea areas, as well as the opening South Atlantic. Another factor for this wide distribution may be the relative lack of everwet zones in the tropics, so the available precipitation was distributed widely and subjected to high evaporation.

\section{Marine biomes and sediments}

Carbonate deposits are abundant in the Cretaceous shelf and epeiric seas, extending to above $40^{\circ}$ north and south, while reefs seem to be limited to $35^{\circ}$ and are most abundant in the northern hemisphere (Figs 6 , 8). Further information on the distribution, composition and structure of Cretaceous reefs is contained in Höfling \& Scott (2002) and Johnson et al. (2002). High latitude reefs are included on their maps, but are based on 'mud mounds', 'siliceous sponge reefs' and 'non-rudist bivalves', rather than hermatypic structures. The details of reef distribution in Europe and North Africa through the Cretaceous have been used to demonstrate that their poleward limit was $30^{\circ}$ north, so as this portion of Tethys moved northward the reef belt appears to be progressively restricted to southern Europe (Voigt et al. 1999). They argued from climate modelling that the reefs were centred on the subtropical high in an area of arid climate, high salinity and nutrient-poor water, similar to their modern counterparts. The motion of the Pacific plate has been reconstructed to show that Early Cretaceous reefs associated with seamounts were confined to the same southern latitudes as their northern hemisphere counterparts (Winterer 1991). The locations of Cretaceous carbonate platforms are contained in a volume edited by Simo et al. (1993).

The details of the various faunal elements of the tropical seas, the 'Mesogean realm', have been reviewed, including the rudist bivalves, dasyclad algae and larger orbitolinid foraminiferans, as well as the colonial scleractinian corals and stromatoporoids (Masse 1992). This high diversity, 'photophilic' community is thought to have been restricted to warm shallow water subject to light penetration to the sea floor, while the presence of peloids, oolites and oncolites confirms that this was a Bahamian-type 
environment. Some latitudinal control was also found in the ammonoids, although by the Late Cretaceous pandemic distributions of genera and many species point to the general breakdown of provinciality. This is attributed to the opening of many migratory pathways (Page 1996). An exception to this was the Western Interior Seaway, as its distinctive faunas were reflective of latitude as well as water mass stringencies. Other Cretaceous groups that have been the subject of worldwide review include the benthic inoceramid bivalves (Dhondt 1992) and the mobile belemnites (Doyle 1992), but these tend to be more common in higher latitudes.

\section{The Tertiary tropics}

The northern continents through the Tertiary remained positioned over the temperate zone with the southern margin parallel with the subtropics, and with southeast Asia projecting south to the Equator as before (Figs 9, 10). The Norwegian Sea, which had acted as a narrow rift during the Mesozoic, began to open, providing an oceanic gateway to the pole, while extensive flooding of central Europe and areas to the east persisted into the Miocene, though somewhat diminished. By the early Tertiary, South America had moved to the south so that Colombia straddled the equator, but in the late Tertiary it reversed its motion to achieve its present position. The Andes, which influence precipitation in South America today, had begun major foreland thrusting about the mid Cretaceous and this progressed through the Tertiary in the central part of this mountain range (Jaillard 1994). However, mountain building in Venezuela and adjacent parts of Colombia did not begin until as recently as the Late Miocene, so the northeast trending part of the arc is very young (Pindell \& Tabbutt 1995). Mid Miocene seas transgressed across Colombia to the upper Amazon Basin along an earlier trend of the Orinoco River, indicating that the modern drainage systems of the continent were established very recently (Hoorn et al. 1995). Africa, India and Australia all moved northward during the Tertiary, with Africa becoming latitudinally symmetrical about the Equator by the Eocene. India moved from the southern to the northern tropics about the same time, while the arrival of Australia in the tropics was a late Tertiary event. The collision of India with Asia in the early Tertiary has had the most obvious tectonic effect of foreshortening the continental area as well as building the highest mountains in the modern world. However, the northward impingements of South America, Africa, and Australia have also profoundly modified the geography by subdividing the world ocean into its present threefold subdivision in the late Tertiary.

Early Tertiary model studies are available that examine the atmosphere (Huber \& Sloan 1999), the oceans (Sloan \& Huber 2001) and the effect on the atmosphere of changing boundary conditions such as topography and vegetation (Sewall et al. 2000). The focus of these experiments was the Late Paleocene to Early Eocene, which is thought to represent the archetypal greenhouse interval with 'tropical' forms such as palm trees up to $49^{\circ}$ north and crocodilians at $71^{\circ}$ in the Canadian Arctic (Greenwood \& Wing 1995; Markwick 1998). Early Tertiary vegetation has been reconstructed, based on a different atmospheric model (Beerling \& Woodward 2001), and it is interesting to compare this approach with the tropical vegetation as reconstructed from the palynological record (Morley 2000 , p. 265). Different terminologies are used, but, in effect, both studies ignore the transitional savanna biomes between the everwet or evergreen zone and the grassland or desert. Also, the sampling coverage is much less complete than for the Cretaceous, being limited to the margins of the larger continents of Africa and South America. Even so, many of the same areas are mapped as rainforest (= evergreen) in these two studies and these include an equatorial belt as well as the margins of the temperate belts in all of the northern and southern hemisphere continents. Where the model and the floral data interpretation differ is in the extent of these rainforest areas. The Morley (2000) interpretation shows up to three times as much vegetative coverage in the tropics compared to the Beerling \& Woodward model (2001). In our view, Morley's interpretation placed unreasonable expectations on the hydrological cycle.

\section{Terrestrial biomes and sediments}

Evidence for early Tertiary coals (Fig. 9) and rainforests is widely dispersed in the tropical and temperate zones, but the data control is limited to a few points in each region, so the total area covered is unknown. The most pervasive control comes from the palynological record and shows that megathermal forests evolved more or less independently in three latitudinal zones as separated by the two subtropical deserts (Morley 2000). According to Morley, the north temperate rainforests are known from the United States and Western Europe, while the south temperate occurrences are found in southern South America and southern Australia. The temperate zone control points are mainly within the latitudinal bands from $40^{\circ}$ to $50^{\circ}$ north or south of the equator. The evidence for low latitude rainforests is restricted to $5^{\circ}$ or $10^{\circ}$ from the equator and is known from South America, Africa, 
India and Southeast Asia. Obviously, the mid-latitude rainforests must have experienced winters without persistent freezes, which would be understandable if the world lacked cold polar fronts. The vegetation model gives a relatively limited distribution of early Tertiary rainforests and is virtually inclusive of the areas of geological evidence (Beerling \& Woodward 2001, p. 268). By the Oligocene and Miocene, the rainforests seem to have retreated to their present-day regions of the tropics (Morley 2000). An exception to this is eastern Africa, from Lake Victoria to the Western Rift (Andrews \& van Couvering 1975), which today is a desert related to the upwelling of the Somalia Current. Interestingly, the rainforests here have been dated as Early Miocene, compatible with the onset of upwelling in the Late Miocene (Prell \& Kutzbach 1992).

Tertiary deserts and related areas that contain evaporite deposits (Fig. 9) seem to be located in the same positions as today, although sampling is limited in large areas of the tropics and subtropics. An interesting area is the mid-latitude desert of Argentina, which today exists because of the rain shadow of the Andes and the relatively low degree of seasonality due to the damping effect of the oceans around this narrow continent. Here the evaporite record through the Tertiary implies the existence of significant elevations in the southern Andes. Changes did affect northern South America, where an upwelling related desert has replaced the rainforests of the early Tertiary. We would attribute the beginning of the upwelling to the drift of this coast northward from the equator. Another area where change may be detected is in eastern China, which has experienced a wet climate only since the late Tertiary. Earlier evaporites could have formed in developing basins (Wang 1985) that were shielded from the coastal zone by marginal mountains.

\section{Marine biomes and sediments}

Carbonate environments were well developed during the early Tertiary and seem to have reached latitudes of about $50^{\circ}$ in both hemispheres, especially in the Eocene (Fig. 10). One of the best-known examples is the Great Australian Bight, which developed 'nontropical shelf carbonate' (Nelson 1988) at this time and has retained it during its northward motion through the temperate zone. The lesson here is that shell layers may form limestone beds along lowgradient land areas where terrigenous sediment dilution is negligible. The northern limit of carbonate deposition occurred in the epeiric and shelf seas of central Europe and the Mediterranean. Here the Eocene faunal elements have been plotted and the limit of the tropical forms determined by the extent of reef-building corals and rich nummulitic assemblages at about $40^{\circ}$ (Popov et al. 2001). The nummulitic facies is reminiscent of the fusulinids of the Late Palaeozoic as well as the orbitolinids of the Early Cretaceous, and may have played a photophilic role like their other large foraminiferal relatives. Worldwide maps of the larger foraminiferans have been compiled for a number of Tertiary intervals, and limits of about $40^{\circ}$ latitude are typical (Adams et al. 1990). The distribution of reefs has also been the subject of a detailed review that contains information on the composition and structure of Tertiary reefs (Perrin 2002).

The meridional barriers between the modern oceans are all late Tertiary effects, and these have been the subject of some interesting biogeographic studies that bear on timing and the consequences of these developments for the tropical oceans. The deep-water connections between the Indian and Atlantic oceans were terminated with the collision of the Arabian and Turkish regions in the Early Miocene. However, transgressions across the thrust-loaded basin here provided intermittent communication of 'warm water' forms until the Late Miocene when the Mediterranean dried up altogether in the 'Messinian Crisis' (Rogl \& Steininger 1984). The present Mediterranean occupies the same latitude as before, but it lacks reefs or extensive carbonate platforms, possibly a limitation imposed by the polar fronts that descend across Europe in the winter. Across the Atlantic, oceanic circulation remained between the Caribbean and Pacific until the Mid Miocene, when a deep sill developed and a distinctive benthic foraminiferal province, related to the cold Californian current, is observed on the Pacific side of Panama (Duque-Caro 1990). This interpretation concludes with the formation of the land barrier by the Late Pliocene, but not until surface currents had been re-established in the Late Miocene. Today, the tropical reef environment is mainly restricted to the Caribbean side, although there are scattered reefs in the Gulf of California and the western coast of Middle America. This shelf is narrow and subject to upwelling, so it is not a favourable site for a carbonate environment. The barrier between Australia and southeast Asia has yet to be finalized, but it is shallow enough to interrupt much of the through flow of equatorial easterly currents. Planktonic foraminiferans have been used to trace the Pacific currents and show that the full development of the modern subtropical gyres did not occur until the Late Miocene (Kennett et al. 1985).

\section{Summary}

The goals of this paper have been to reassess the value 
of coals, evaporites, reefs and carbonates as indicators of tropical climates, and to document the record of these deposits through nearly 300 million years of Earth history. Admittedly the geological record of the tropics is patchy, especially for the continental interiors and the ocean basins, so a prime concern is the reliability of the data as plotted. In the following paragraphs we discuss pole-to-pole histograms that show the latitudinal frequency of the sediment types, present and past, and we mention some biases perceived in the data. Initially, we compare the present position of each of the sediment types with the summed data of the past, and then we examine the past distributions to detect any long-term trends. Obviously, the Hadley circulation dominates the tropical climate today, and we will examine the influence it has on the patterns observed in the climatesensitive sediments.

Precipitation, as a function of latitude, may be examined in the pole-to-pole frequency diagrams of the peats and evaporites (Figs 11, 12). First, there is an obvious bias toward the northern hemisphere because there are more depositional sites for the present, as well as the palaeogeographic history since the Jurassic. Despite this, the peaks representing modern temperate and tropical peats, together with the intervening subtropical evaporite peaks, are clearly seen and correlate well with the latitudinal balance of precipitation and evaporation today (Jaeger 1976). The bimodal evaporite peaks of the past are displaced toward the equator by about $10^{\circ}$ relative to today. This is an inherent bias due to the geological record being skewed toward the lowland coastal deposits, while the higher-latitude deserts typical of the continental interiors are less likely to be preserved. Present-day peats of the south temperate latitudes are truncated simply because the continents terminate between $35^{\circ}$ and $55^{\circ}$ south. Taking these factors into account the geological record as a whole provides a faithful record of the precipitation balance for coastal, or maritime, climates. For any given latitude, the evaporites and coals overlap, but on average the evaporites are seen to prevail in the range $10^{\circ}$ to $40^{\circ}$ and thus define subtropical belts that confine the tropical rainy belt to a narrow zone along the Equator. As can be seen from the present-day map (Fig. 1), there are many exceptions to the strict zonal pattern and we can certainly expect these variances to have occurred in the geological past.

The present and past reef and carbonate distributions are also plotted as a function of latitude (Figs 13, 14) and show some interesting patterns. Modern reef and carbonate plots are similar due simply to reefs being the most obvious element of the carbonate system, so that there is an inherent bias at the data assembly level. The modern reef histogram shows the well-known latitudinal limits near $30^{\circ}$, while a trough near the equator reflects the detrimental effects on the reef ecosystem of open ocean upwelling in some areas and coastal runoff related to the ITCZ in other areas. The number of modern reefs is high compared to the total for all 16 geological intervals combined and should provide a cautionary note concerning the reliability of the fossil record of reefs. Huge areas like the Pacific Ocean today encompass vast reef tracts, yet the fate of past oceanic settings was to be subducted or deformed against continental margins, making the reef remnants difficult to interpret. Some

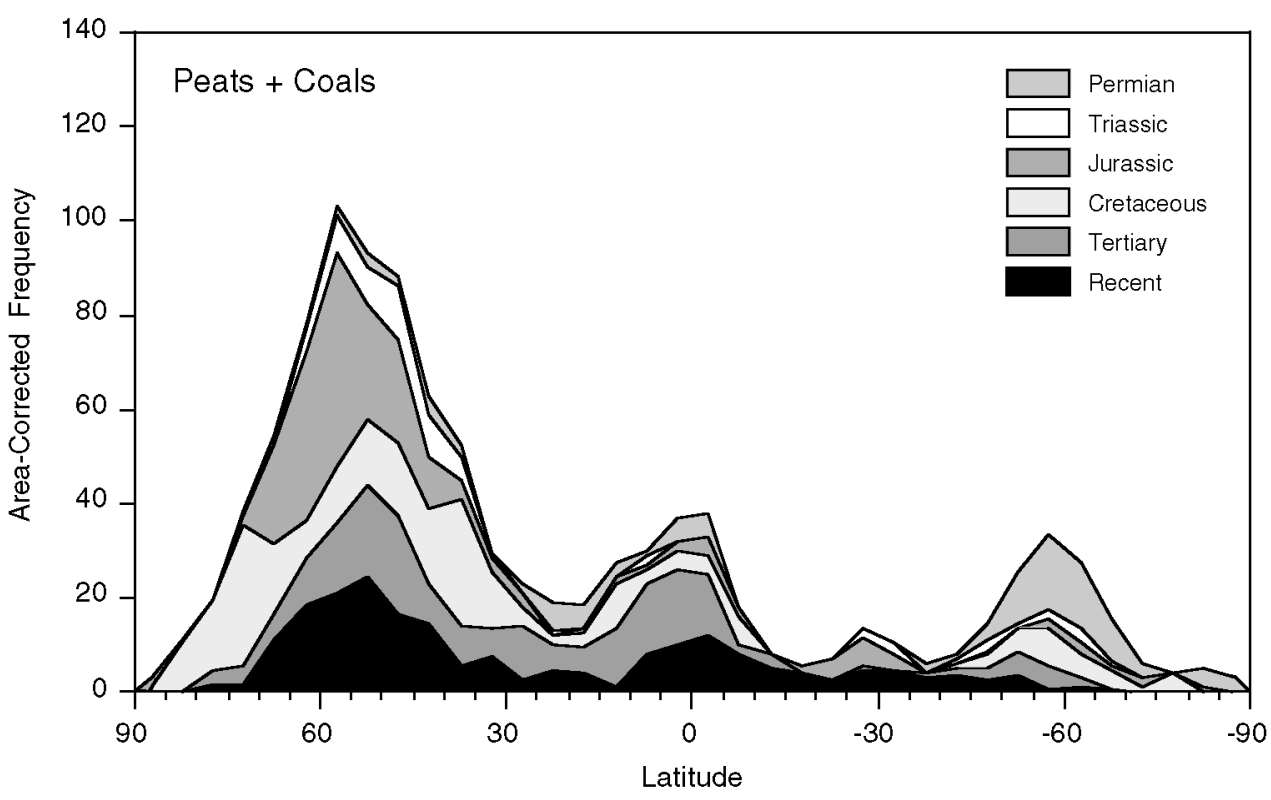

Fig. 11. Latitudinal frequency of coals (or peats) as summed by geological period from the Permian to the present. The data counts have been limited to one site per $5^{\circ}$ latitude and longitude quadrangle to minimize sampling bias and an adjustment has been made to account for the change in area of the quadrangles over the latitudinal range. 


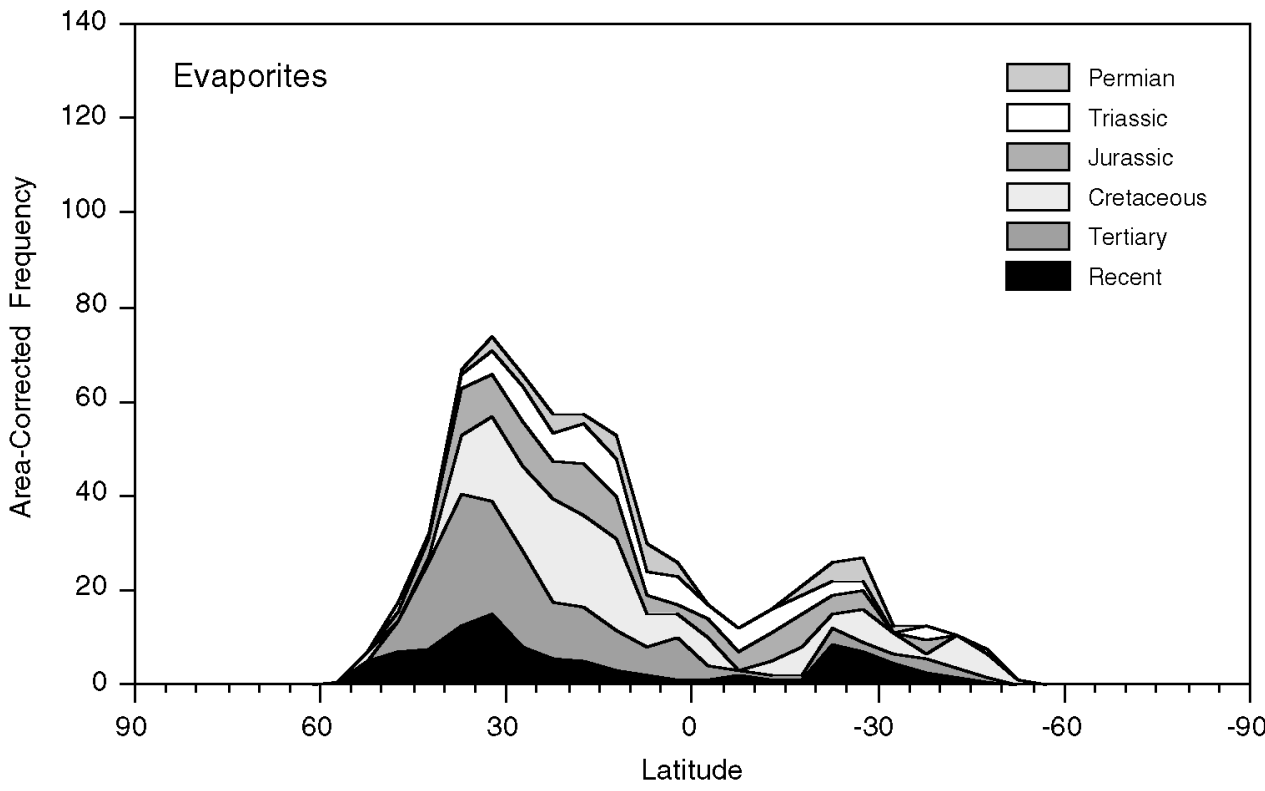

Fig. 12. Latitudinal frequency of evaporites as summed by geological period from the Permian to the present. The data counts have been limited to one site per $5^{\circ}$ latitude and longitude quadrangle to minimize sampling bias and an adjustment has been made to account for the change in area of the quadrangles over the latitudinal range. authors have suggested that there was an asymmetry toward reef development in the northern hemisphere in the past, but the peak at $30^{\circ} \mathrm{N}$ is largely due to the accidental upthrusting along the Alpine zone and to the popularity of this area for field studies. The latitudinal limit of fossil reefs is similar to today's, given the limits of accuracy of the palaeogeographic reconstructions. The carbonates in general extend to $50^{\circ}$ in areas of low gradients and clastic runoff, and the northern hemisphere asymmetry of this curve is related to the broad epeiric seaways of Europe and adjacent Russia.

\section{Conclusions}

The latitudinal plots of the climate-sensitive sediments confirm the dominance through time of the Hadley cells on tropical circulation patterns. The evaporite belts coincide with the latitudes occupied by the subtropical highs today and confirm that they have remained in the same broad bands through long periods of geological time. The evaporites are directly tied to the hot dry conditions generated by the descending limbs of the Hadley cells. We find that there are variations in the number of evaporite
Fig. 13. Latitudinal frequency of reefs as summed by geological period from the Permian to the present. The data counts have been limited to one site per $5^{\circ}$ latitude and longitude quadrangle to minimize sampling bias and an adjustment has been made to account for the change in area of the quadrangles over the latitudinal range.

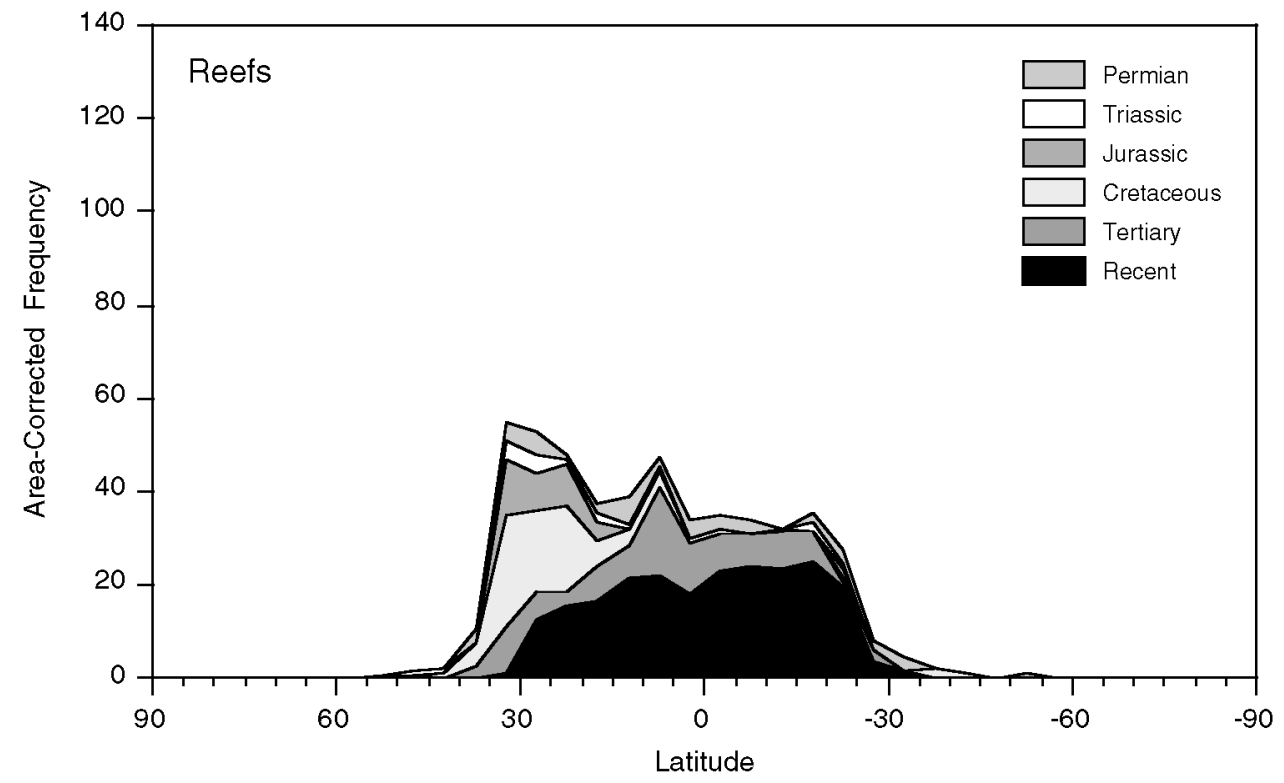


Fig. 14. Latitudinal frequency of carbonates as summed by geological period from the Permian to the present. The data counts have been limited to one site per $5^{\circ}$ latitude and longitude quadrangle to minimize sampling bias and an adjustment has been made to account for the change in area of the quadrangles over the latitudinal range.

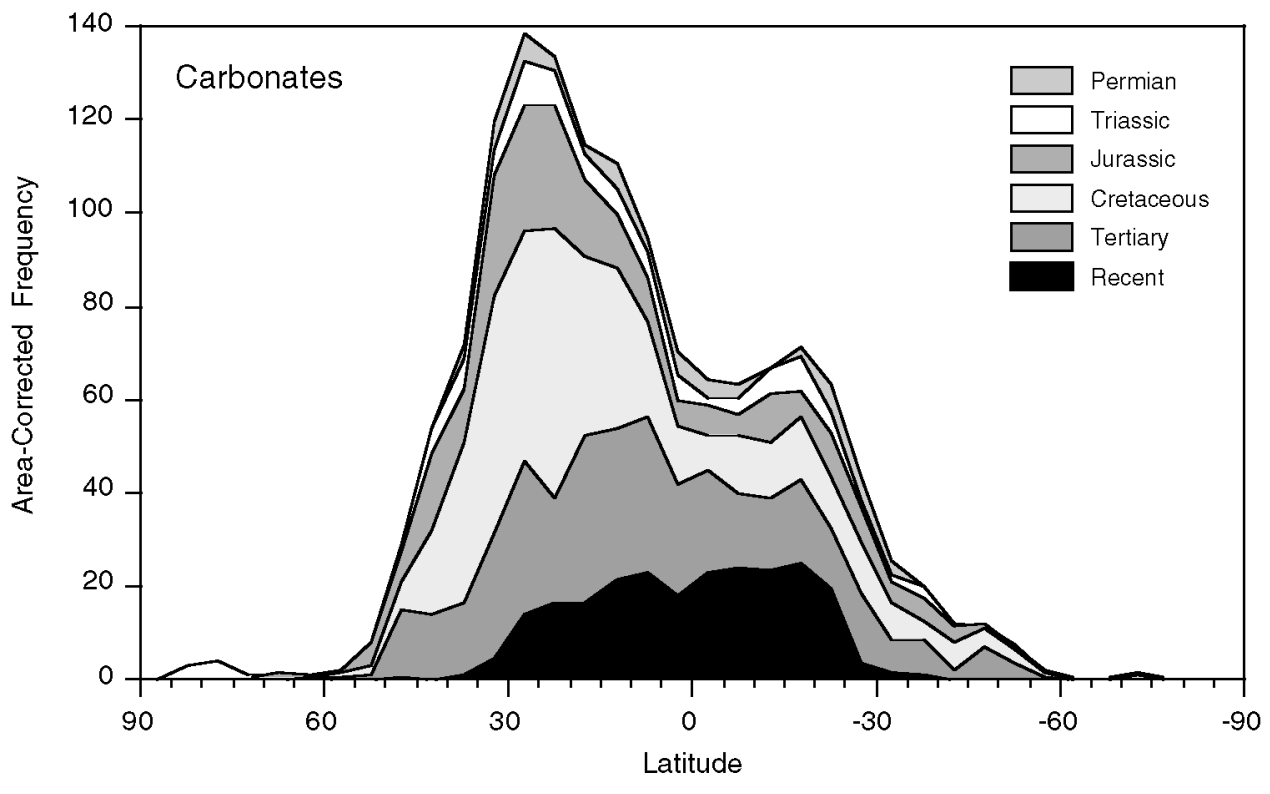

deposits through time, but relate this to the availability of epeiric and shelf sea basins within the subtropical latitudes broadly defined. Importantly, we observe that high evaporation may occur directly offshore from peat swamps today and we show that examples are seen along a number of east-facing coasts (Fig. 1). Here, warm currents like the Gulf Stream or the Kiroshio Current provide the moisture and the diurnal rainfall effect results in rain on the adjacent coastal swamps. The significance for the geological record is that evaporites may be deposited in close juxtaposition to coal swamps; the Mid Jurassic to Early Cretaceous record of the Algerian basin is a good example of this phenomenon. Again, a higher level of continental flooding, typical of the geological past, would favour this development. The presence of evaporite lagoons in the Bahamas to the windward of the Florida peat swamps seems to provide a modern analogue.

Reefs, like evaporites, form a low-latitude bimodal distribution, but with the peaks slightly closer to the equator. Again, the Hadley cell is implicated because precipitation and clastic runoff are detrimental to reef growth. More importantly, the subtropical highs drive the oceanic gyres, which have marginal upwelling, also unfavourable for reef growth, while the centres are characterized by clear water related to downwelling. The fact that the world's most diverse marine communities coincide with the least productive waters is called 'the nutrient paradox' (Hallock \& Schlager 1986). The explanation is that the key reef organisms depend on light for photosynthesis while abundant nutrients stimulate plankton growth, which in turn curtails water transparency. Primary producers occur on reefs, but the corals, benthic foraminiferans and other forms are 'mixotrophs', that is, they harbour algal symbionts, and recycling of nutrients occurs between hosts and symbionts. The whole strategy of the reef in the first place is to maintain a position within the photic zone so that light penetration is maximized. The best correlates to downwelling and to reef distribution are the dynamic sea highs (Fig. 2) because they show the characteristic displacement towards the western sides of the oceans. Most authorities stress temperature as controlling reef distribution and, while temperature maxima extend to higher latitudes on the western sides of oceans, the reefs, by this argument, should be well developed in a narrow band on the eastern sides of the oceans, but are not. Also, one would expect reefs to occur at significantly higher latitudes at warmer times in the past, but we argue that the major hermatypic structures are confined to present limits. The modelling community could test the downwelling concept by generating maps showing sea surface highs and comparing the highs with the reef zones.

Tropical peats have had a much more varied distribution through time and apparently this is true of rainforests as well. The Permian Cathaysian province of China contains floras indicative of rainforests, including leaves with drip tips, vines with large leaves and wood lacking growth rings (Yao 1983; Li \& Wu 1996). Broadly speaking, these forms were descended from the Carboniferous coal swamp floras shared by China with Europe and North America. The assembly of Pangea and the withdrawal of its epeiric seas resulted in a continent with a profound monsoonal climate. So, the Euramerican 
rainforests were terminated in the Early Permian at the time their Cathaysian descendants were thriving far to the east of Pangea. Early Triassic swamp floras, tropical and temperate, are absent from the geological record, but Late Triassic through Mid Jurassic coals of Mexico formed under equatorial conditions and are potential rainforest candidates in a Pangean world. The monsoonal circulation was still active, but climate models show that the least seasonal areas in terms of precipitation were along the western margin of the supercontinent. As the central Atlantic Ocean opened, coals developed in Algeria from the Mid Jurassic into the earliest Cretaceous and climate modelling indicates that this zone continued along the southeastern margin of the opening ocean. Equatorial coals persisted through the Early Cretaceous in Peru and may represent a continuation of the system in Mexico (see above). In this scenario, the rainforests tracked the equator as the continent moved northward. Mid Cretaceous rainforests appear to be absent from the record and here the quality of the palynological record is complete enough to conclude that the entire tropical area of Africa and South America was populated by semi-arid floras. At this time the area of continent along the equator was at a maximum and sedimentological studies indicate that seasonal rainfall prevailed. We reiterate the suggestion that the ITCZ showed a wide seasonal excursion during this time (Ziegler et al. 1987) and we add that the total precipitation may have been limited because of the magnitude of the continent.

It has been implied that the rainforests originated in the Late Cretaceous (Morley 2000), and, in view of the above discussion, we would modify this statement with the words 'modern' and 'angiosperm-dominated' rainforests. Evidently, the opening of the South Atlantic and the transgression of the seas had reached a point by the Late Cretaceous that rainforests were common along the equator in South America and Africa. This has been established by simply matching the palynofloras with modern denizens of the rainforests, while the existence of everwet climates in the Late Cretaceous is confirmed by the appearance of coals. By the early Tertiary this equatorial rainforest belt was joined by temperate latitude equivalents in both hemispheres, although the taxonomic composition of each belt is distinct, reflecting the geographic isolation due to the intervening desert zones. The term 'tropical' has been applied to the Temperate Zone occurrences and Morley (2000) has modified this to 'Boreotropical'. We feel the term 'temperate rainforest' is satisfactory because the floras are taxonomically distinct from their equatorial counterparts, and they must have experienced some seasonality in terms of the annual zenith angle variation. After all, temperate swamps of the Gulf Coast today contain 'tropical' forms like palms and crocodilians, yet we still refer to them as 'temperate'. They receive precipitation daily and they would differ from their early Tertiary counterparts in lacking the cold intrusions of polar air in the winter. By the late Tertiary, these Temperate Zone rainforests were diminished, and the tropical equivalents prevailed as today.

In this paper we have stressed the ways in which tropical diversity is dependent on factors other than temperature. This is simply because temperatures sufficient for life occur throughout the tropics and subtropics today, while this wide latitudinal belt contains communities, marine and terrestrial, that span the range from the lowest to the highest diversities found on Earth. On the land surface the most diverse and productive forests occur where precipitation is continuous through the annual cycle, and such areas depend on geographical configurations that serve to 'dampen' the natural seasonal tendency of the climate. Maritime climates have this effect while continental climates, related to collisions or low sea level stands, do not favour high tropical productivity or diversity. In the ocean, diversity is favoured by light penetration to the sea floor, while high biological productivity is observed in the planktonic communities. Photophilic communities thrive in areas of downwelling, while the opposite is true of the nutrient-dependent surface communities. These contrasting life styles occupy opposite sides of the same oceans and indicate the importance of variations in longitude rather than simply latitude.

Acknowledgements. - We acknowledge the support of the U.S. National Science Foundation grant ATM 00-00545.

\section{References}

Adams, C.G., Lee, D.E. \& Rosen, B.R. 1990: Conflicting isotopic and biotic evidence for tropical sea-surface temperatures during the Tertiary. Palaeogeography, Palaeoclimatology, Palaeoecology 77, 289-313.

Andrews, P. \& van Couvering, A.H. 1975: Palaeoenvironments in the East African Miocene. In Szalay, F.S. (ed.): Approaches to Primate Paleobiology, 62-103. Karger, Basel.

Barale, G., Zarbout, M. \& Philippe, M. 1998: Niveaux à végétaux fossiles en environnement fluviatile à marin proximal dans le Dahar (Bathonien à Albien - Sud Tunisien). Bulletin de la Societe Geologique de France 169, 811-819.

Barry, R.G. \& Chorley, R.J. 1998: Atmosphere, Weather and Climate, 7th edn. 409 pp. Routledge, London.

Beerling, D.J. \& Woodward, F.I. 2001: Vegetation and the Terrestrial Carbon Cycle: Modelling the First 400 Million Years, 405 pp. Cambridge University Press, Cambridge.

Belasky, P. 1994: Biogeography of Permian corals and the determination of longitude in tectonic reconstructions of the Paleopacific region. Canadian Society of Petroleum Geologists, Memoir 17, 621-646.

Bellwood, D.R. \& Hughes, T.P. 2001: Regional-scale assembly rules and biodiversity of coral reefs. Science 292, 1532-1534. 
Benton, M.J., Bouaziz, S., Buffetaut, E., Martill, D., Ouaja, M., Soussi, M. \& Trueman, C. 2000: Dinosaurs and other fossil vertebrates from fluvial deposits in the Lower Cretaceous of southern Tunisia. Palaeogeography, Palaeoclimatology, Palaeoecology 157, 227-246.

Bush, A.B.G. \& Philander, S.G.H. 1997: The Late Cretaceous: simulation with a coupled atmosphere-ocean general circulation model. Paleoceanography 12, 495-516.

Busson, G. 1970: Le Mésozoïque saharien. 2e partie: essai de synthèse des données des sondages algéro-tunisiens, tome II. Centre de Recherches sur les Zones Arides, Série Géologie 11, 351811.

Busson, G. \& Cornée, A. 1991: The Sahara from the Middle Jurassic to the Middle Cretaceous: data on environments and climates based on outcrops in the Algerian Sahara. Journal of African Earth Sciences 12, 85-105.

Cecca, F. 1999: Palaeobiogeography of Tethyan ammonites during the Tithonian (latest Jurassic). Palaeogeography, Palaeoclimatology, Palaeoecology 147, 1-37.

Chandler, M.A. 1994: Depiction of modern and Pangean deserts: evaluation of GCM hydrological diagnostics for paleoclimate studies. Geological Society of America Special Paper 288, 117-138.

Chandler, M.A., Rind, D. \& Ruedy, R. 1992: Pangaean climate during the Early Jurassic: GCM simulations and the sedimentary record of paleoclimate. Geological Society of America Bulletin 104, 543-559.

Collins, M. 1990: The Last Rainforests: a World Conservation Atlas, 200 pp. Oxford University Press, New York.

Coates, A.G., Jackson, J.B.C., Collins, L.S., Cronin, T.M., Dowsett, H.J., Bybell, L.M., Jung, P. \& Obando, J.A. 1992: Closure of the Isthmus of Panama: the near-shore marine record of Costa Rica and western Panama. Geological Society of America Bulletin 104, 814-828.

DeConto, R.M., Hay, W.W., Thompson, S.L. \& Bergengren, J. 1999: Late Cretaceous climate and vegetation interactions: cold continental interior paradox. Geological Society of America Special Paper 332, 391-406.

Dhondt, A.V. 1992: Cretaceous inoceramid biogeography: a review. Palaeogeography, Palaeoclimatology, Palaeoecology 92, 217-232.

Dino, R., Pocknall, D.T. \& Dettmann, M.E. 1999: Morphology and ultrastructure of elater-bearing pollen from the Albian to Cenomanian of Brazil and Ecuador: implications for botanical affinity. Review of Palaeobotany and Palynology 105, 201-235.

Doyle, P. 1992: A review of the biogeography of Cretaceous belemnites. Palaeogeography, Palaeoclimatology, Palaeoecology 92, 207-216.

Dubiel, R.F., Parrish, J.T., Parrish, J.M. \& Good, S.C. 1991: The Pangean megamonsoon - evidence from the Upper Triassic Chinle Formation, Colorado Plateau. Palaios 6, 347-370.

Duque-Caro, H. 1990: Neogene stratigraphy, paleoceanography and paleobiogeography in northwest South America and the evolution of the Panama Seaway. Palaeogeography, Palaeoclimatology, Palaeoecology 77, 203-234.

Flügel, E. 2002: Triassic reef patterns. SEPM (Society for Sedimentary Geology) Special Publication 72, 391-463.

Fraser, R.H. \& Currie, D.J. 1996: The species richness-energy hypothesis in a system where historical factors are thought to prevail: coral reefs. The American Naturalist 148, 138-159.

Gibbs, M.T., Rees, P.M., Kutzbach, J.E., Ziegler, A.M., Behling, P.J. \& Rowley, D.B. 2002: Simulations of Permian climate and comparisons with climate-sensitive sediments. Journal of Geology $110,33-55$

Gordon, W.A. 1975: Distribution by latitude of Phanerozoic evaporite deposits. Journal of Geology 83, 671-684.

Greenwood, D.R. \& Wing, S.L. 1995: Eocene continental climates and latitudinal temperature gradients. Geology 23, 1044-1048.

Gyllenhaal, E.D., Engberts, C.J., Markwick, P.J., Smith, L.H. \& Patzkowsky, M.E. 1991: The Fujita-Ziegler model: a new semiquantitative technique for estimating paleoclimate from paleogeographic maps. Palaeogeography, Palaeoclimatology, Palaeoecology 86, 41-66.

Hallock, P. \& Schlager, W. 1986: Nutrient excess and the demise of coral reefs and carbonate platforms. Palaios 1, 389-398.
Herman, A.B. \& Spicer, R.A. 1996: Palaeobotanical evidence for a warm Cretaceous Arctic Ocean. Nature 380, 330-333.

Höfling, R. \& Scott, R.W. 2002: Early and mid-Cretaceous buildups. SEPM (Society for Sedimentary Geology) Special Publication $72,521-548$.

Holz, M. \& Scherer, C.M.S. 2000: Sedimentological and paleontological evidence of paleoclimatic change during the Southbrazilian Triassic: the register of a global trend towards a humid paleoclimate. Zentralblatt für Geologie und Paläontologie 11-12, 1589-1609.

Hoorn, C., Guerrero, J., Sarmiento, G.A. \& Lorente, M.A. 1995: Andean tectonics as a cause for changing drainage patterns in Miocene northern South America. Geology 23, 237-240.

Huber, M. \& Sloan, L.C. 1999: Warm climate transitions: a general circulation modeling study of the Late Paleocene Thermal Maximum ( $56 \mathrm{Ma})$. Journal of Geophysical Research 104, $16633-16655$.

Ittekot, V., Haake, B., Bartsch, M., Nair, R.R. \& Ramaswamy, V. 1992: Organic carbon removal in the sea: the continental connection. In Summerhayes, C.P., Prell, W.L. \& Emeis, K.C. (eds): Upwelling Systems: Evolution Since the Miocene. Geological Society Special Publications 64, 167-176.

Jaeger, L. 1976: Monatskarten des Niederschlags für die ganze Erde. Berichte des Deutschen Wetterdienstes 139, 1-38.

Jaillard, E. 1994: Kimmeridgian to Paleocene tectonic and geodynamic evolution of the Peruvian (and Ecuadorian) margin. In Salfity, J.A. (ed.): Cretaceous Tectonics of the Andes, 101-167. Vieweg, Braunschweig.

Jenkins, G.S. 1996: A sensitivity study of changes in Earth's rotation rate with an atmospheric general circulation model. Global and Planetary Change 11, 141-154.

Jenkyns, H.C. \& Wilson, P.A. 1999: Stratigraphy, paleoceanography, and evolution of Cretaceous Pacific guyots: relics from a greenhouse Earth. American Journal of Science 299, 341-392.

Jin, Y.G. \& Shang, Q.H. 1997: Palaeobiogeographic evolution of Permian brachiopods. In Jin, Y.G. \& Dinely, D. (eds): Palaeontology and Historical Geology. Proceedings, 30th International Geological Congress 12, 29-53.

Johnson, C.C., Sanders, D., Kauffman, E.G. \& Hay, W.W. 2002: Patterns and processes influencing Upper Cretaceous reefs. SEPM (Society for Sedimentary Geology) Special Publication 72, 549-586.

Kagan, B.A. 1997: Earth-Moon tidal evolution: model results and observational evidence. Progress in Oceanography 40, 109-124.

Kathiresan, K. \& Bingham, B.L. 2001: Biology of mangroves and mangrove ecosystems. Advances in Marine Biology 40, 81-251.

Kennett, J.P., Keller, G. \& Srinivasan, M.S. 1985: Miocene planktonic foraminiferal biogeography and paleoceanographic development of the Indo-Pacific region. Geological Society of America Memoir 163, 197-236.

Kiessling, W., Flügel, E. \& Golonka, J. (eds) 2002: Phanerozoic reef patterns. SEPM (Society for Sedimentary Geology) Special Publication 72, $775 \mathrm{pp}$.

Kim, S.-J. \& Crowley, T.J. 2000: Increased Pliocene North Atlantic Deep Water: cause or consequence of Pliocene warming? Paleoceanography 15, 451-455.

Kobayashi, F. 1999: Tethyan uppermost Permian (Dzhulfian and Dorashamian) foraminiferal faunas and their paleogeographic and tectonic implications. Palaeogeography, Palaeoclimatology, Palaeoecology 150, 279-307.

Kottlowski, F.E., Cross, A.T. \& Meyerhoff, A.A. (eds) 1978: Coal Resources of the Americas, Selected Papers. Geological Society of America Special Paper 179, 1-90.

Kutzbach, J.E., Gallimore, R., Harrison, S., Behling, P., Selin, R. \& Laarif, F. 1998: Climate and biome simulations for the past 21,000 years. Quaternary Science Reviews 17, 473-506.

Lefranc, J.P. \& Guiraud, R. 1990: The Continental Intercalaire of northwestern Sahara and its equivalents in the neighbouring regions. Journal of African Earth Sciences 10, 27-77.

Leinfelder, R.R., Schmid, D.U., Nose, M. \& Werner, W. 2002: Jurassic reef patterns - the expression of a changing globe. SEPM Special Publication 72, 465-520. 
Lemoigne, Y. 1984: Données nouvelles sur la paléoflore de Colombie. Geobios 17, 667-690.

Li, X. \& Wu, X. 1996: Late Paleozoic phytogeographic provinces in China and its adjacent regions. Review of Palaeobotany and Palynology 90, 41-62.

Lottes, A.L. \& Ziegler, A.M. 1994: World peat occurrence and the seasonality of climate and vegetation. Palaeogeography, Palaeoclimatology, Palaeoecology 106, 23-37.

Manspeizer, W. 1994: The breakup of Pangea and its impact on climate: consequences of Variscan-Alleghanide orogenic collapse. Geological Society of America Special Paper 288, 169-185.

Markwick, P.J. 1998: Fossil crocodilians as indicators of Late Cretaceous and Cenozoic climates: implications for using palaeontological data in reconstructing palaeoclimate. Palaeogeography, Palaeoclimatology, Palaeoecology 137, 205-271.

Masse, J.P. 1992: The Lower Cretaceous Mesogean benthic ecosystems: palaeoecologic aspects and palaeobiogeographic implications. Palaeogeography, Palaeoclimatology, Palaeoecology 91, 331-345.

Mei, S. \& Henderson, C.M. 2001: Evolution of Permian conodont provincialism and its significance in global correlation and paleoclimate implication. Palaeogeography, Palaeoclimatology, Palaeoecology 170, 237-260.

Metcalfe, I. 1994: Late Palaeozoic and Mesozoic palaeogeography of eastern Pangea and Tethys. Canadian Society of Petroleum Geologists Memoir 17, 97-111.

Moore, G.T., Hayashida, D.N., Ross, C.A. \& Jacobson, S.R. 1992: Paleoclimate of the Kimmeridgian/Tithonian (Late Jurassic) world: I. Results using a general circulation model. Palaeogeography, Palaeoclimatology, Palaeoecology 93, 113-150.

Moore, G.T. \& Ross, C.A. 1994: Kimmeridgian-Tithonian (Late Jurassic) dinosaur and ammonoid paleoecology from a paleoclimate simulation. Canadian Society of Petroleum Geologists Memoir 17, 345-361.

Morley, R.J. 2000: Origin and Evolution of Tropical Rainforests. Wiley, New York, 362 pp.

Negrelle, R.R.B. 2002: The Atlantic forest in the Volta Velha Reserve: a tropical rainforest site outside the tropics. Biodiversity and Conservation 11, 887-919.

Nelson, C.S. 1988: An introductory perspective on non-tropical shelf carbonates. Sedimentary Geology 60, 3-12.

Olsen, P.E. \& Kent, D.V. 2000: High-resolution early Mesozoic Pangean climatic transect in lacustrine environments. Zentralblatt für Geologie und Paläontologie 11-12, 1475-1495.

Page, K.N. 1996: Mesozoic ammonoids in space and time. In Landman, N.H., Tanabe, K. \& Davis, R.A. (eds): Ammonoid Paleobiology, 755-794. Plenum Press, New York.

Parrish, J.T. 1993: Climate of the supercontinent Pangea. Journal of Geology 101, 215-233.

Parrish, J.T. 1998: Interpreting Pre-Quaternary Climate from the Geologic Record, 338 pp. Columbia University Press, New York.

Parrish, J.T., Ziegler, A.M. \& Scotese, C.R. 1982: Rainfall patterns and the distribution of coals and evaporites in the Mesozoic and Cenozoic. Palaeogeography, Palaeoclimatology, Palaeoecology 40, 67-101.

Perrin, C. 2002: Tertiary: the emergence of modern reef ecosystems. SEPM (Society for Sedimentary Geology) Special Publication 72, 587-621.

Person, C.P. \& Delevoryas, T. 1982: The Middle Jurassic flora of Oaxaca Mexico. Palaeontographica B 180, 82-119.

Pindell, J.L., Cande, S.C., Pitman, W.C., Rowley, D.B., Dewey, J.F., Labrecque, J. \& Haxby, W. 1988: A plate-kinematic framework for models of Caribbean evolution. Tectonophysics 155, 121-138.

Pindell, J.L. \& Tabbutt, K.D. 1995: Mesozoic-Cenozoic Andean paleogeography and regional controls on hydrocarbon systems. In Tankard, A.J., Suarez, S. \& Welsink, H.J. (eds): Petroleum Basins of South America. American Association of Petroleum Geologists Memoir 62, 101-128.

Pollard, D. \& Schulz, M. 1994: A model for the potential locations of Triassic evaporite basins driven by paleoclimatic GCM simulations. Global and Planetary Change 9, 233-249.

Popov, S.V., Akhmetiev, M.A., Bugrova, E.M., Lopatin, A.V., Amitrov, O.V., Andreeva-Grigorovich, A.S., Zherikhin, V.V.,
Zaporozhets, N.I., Nikolaeva, I.A., Krasheninnikov, V.A., Kuzmicheva, E.I., Sytchevskaya, E.K. \& Shcherba, I.G. 2001: Biogeography of the Northern Peri-Tethys from the Late Eocene to the Early Miocene: Part 1. Late Eocene. Paleontological Journal 35, Supplement 1, 1-68.

Poulsen, C.J., Barron, E.J., Johnson, C.C. \& Fawcett, P. 1999: Links between major climatic factors and regional oceanic circulation in the mid-Cretaceous. In Barrera, E. \& Johnson, C.C. (eds): Evolution of the Cretaceous Ocean Climate System. Geological Society of America Special Paper 332, 73-89.

Poulsen, C.J., Barron, E.J., Arthur, M.A. \& Peterson, W.H. 2001: Response of the mid-Cretaceous global oceanic circulation to tectonic and CO2 forcings. Paleoceanography 16, 576-592.

Prell, W.L. \& Kutzbach, J.E. 1992: Sensitivity of the Indian monsoon to forcing parameters and implications for its evolution. Nature 360, 647-652.

Price, G.D., Sellwood, B.W. \& Valdes, P.J. 1995: Sedimentological evaluation of general circulation model simulations for the 'greenhouse' Earth: Cretaceous and Jurassic case studies. Sedimentary Geology 100, 159-180.

Rees, P.M. 2002: Land-plant diversity and the end-Permian mass extinction. Geology 30, 827-830.

Rees, P.M., Ziegler, A.M., Gibbs, M.T., Kutzbach, J.E., Behling, P.J. \& Rowley, D.B. 2002: Permian phytogeographic patterns and climate data/model comparisons. Journal of Geology 110, 1-31.

Rees, P.M., Ziegler, A.M. \& Valdes, P.J. 2000: Jurassic phytogeography and climates: new data and model comparisons. In Huber, B.T., Macleod, K.G. \& Wing, S.L. (eds): Warm Climates in Earth History, 297-318. Cambridge University Press, Cambridge.

Retallack, G.J., Veevers, J.J. \& Morante, R. 1996: Global coal gap between Permian-Triassic extinction and Middle Triassic recovery of peat-forming plants. Geological Society of America Bulletin 108, 195-207.

Rogl, F. \& Steininger, F.F. 1984: Neogene Paratethys, Mediterranean and Indo-pacific seaways, implications for the paleobiogeography of marine and terrestrial biotas. In Brenchley, P.J. (ed.): Fossils and Climate, 171-200. Wiley, New York.

Rosen, B.R. 1988: Progress, problems and patterns in the biogeography of reef corals and other tropical marine organisms. Helgoländer Meeresunters 42, 269-301.

Ross, C.A. 1995: Permian Fusulinaceans. In Scholle, P.A., Peryt, T.M. \& Ulmer-Scholle (eds): The Permian of Northern Pangea Volume 1, Paleogeography, Paleoclimates, Stratigraphy, 167-185. Springer-Verlag, Berlin.

Ross, C.A., Moore, G.T. \& Hayashida, D.N. 1992: Late Jurassic paleoclimate simulation - paleoecological implications for ammonoid provinciality. Palaios 7, 487-507.

SeaWiFS Project. 2002: NASA Goddard Space Flight Center. http://seawifs.gsfc.nasa.gov/SEAWIFS.html.

Sellwood, B.W., Valdes, P.J. \& Price, G.D. 2000: Geological evaluation of multiple general circulation model simulations of Late Jurassic palaeoclimate. Palaeogeography, Palaeoclimatology, Palaeoecology 156, 147-160.

Sereno, P.C., Beck, A.L., Dutheil, D.B., Larsson, H.C.E., Lyon, G.H., Moussa, B., Sadleir, R.W., Sidor, C.A., Varricchio, D.J., Wilson, G.P. \& Wilson, J.A. 1999: Cretaceous sauropods from the Sahara and the uneven rate of skeletal evolution among dinosaurs. Science 286, 1342-1347.

Sereno, P.C., Larsson, H.C.E., Sidor, C.A. \& Gado, B. 2001: The giant crocodyliform Sarcosuchus from the Cretaceous of Africa. Science 294, 1516-1519.

Sewall, J.O., Sloan, L.C., Huber, M. \& Wing, S. 2000: Climate sensitivity to changes in land surface characteristics. Global and Planetary Change 26, 445-465.

Shi, G.R. \& Archbold, N.W. 1993: Permian marine provinciality, a theoretical model and an empirical comparison. In Wallis, R.L. \& Shi, G.R. (eds): Environmental Management in Asia - Training, Education and Research. Proceedings, 14th Biennial Conference of the Asian Association for Biology Education, 155-182.

Silva, A., da, Young, A.C. \& Levitus, S. 1994: Atlas of Surface Marine Data 1994, Volume 1, Algorithms and Procedures. NOAA Atlas NESDIS 6. U.S. Department of Commerce, Washington D.C. 
Simo, J.A.T., Scott, R.W. \& Masse, J.P. (eds) 1993: Cretaceous Carbonate Platforms. AAPG (The American Association of Petroleum Geologists) Memoir 56, 479 pp.

Sloan, L.C., Crowley, T.J. \& Pollard, D. 1996: Modeling of middle Pliocene climate with NCAR GENESIS general circulation model. Marine Micropaleontology 27, 51-61.

Sloan, L.C. \& Huber, M. 2001: Eocene oceanic responses to orbital forcing on precessional time scales. Paleoceanography 16, 101111.

Tollmann, A. \& Kristan-Tollmann, E. 1985: Paleogeography of the European Tethys from Paleozoic to Mesozoic and the Triassic relations of the eastern part of Tethys and Panthalassa. In Nakazawa, K. \& Dickins, J.M. (eds): The Tethys, Her Paleogeography and Paleobiogeography from Paleozoic to Mesozoic, 3-22. Tokai University Press, Tokyo.

Tomlinson, P.B. 1986: The Botany of Mangroves, 413 pp. Cambridge University Press, Cambridge.

Upchurch, G.R., Otto-Bliesner, B.L. \& Scotese, C.R. 1999: Terrestrial vegetation and its effects on climate during the latest Cretaceous. Geological Society of America Special Paper 332, 407426.

Valdes, P.J., Sellwood, B.W. \& Price, G.D. 1996: Evaluating concepts of Cretaceous equability. Palaeoclimates 2, 139-158.

Valyashko, M.G. 1972: Scientific works in the field of geochemistry and the genesis of salt deposits in the USSR. In RichterBernburg, G. (ed.): Geology of Saline Deposits: Proceedings of the Hanover Symposium, 289-311. UNESCO, Paris.

Vergara, L. 1997: Stratigraphy, foraminiferal assemblages and paleoenvironments in the Late Cretaceous of the Upper Magdalena Valley, Colombia (Part I). Journal of South American Earth Sciences 10, 111-132.

Veron, J.E.N. 1993: A biogeographic database of hermatypic corals. Australian Institute of Marine Science 10, $433 \mathrm{pp}$.

Veron, J.E.N. 1995: Corals in Space and Time: The Biogeography and Evolution of the Scleractinia, $321 \mathrm{pp}$. Comstock/Cornell, Ithaca.

Villamil, T., Arango, C. \& Hay, W.W. 1999: Plate tectonic paleoceanographic hypothesis for Cretaceous source rocks and cherts of northern South America. Geological Society of America Special Paper 332, 191-202.

Visscher, H. \& Zwan, C.J., van der. 1981: Palynology of the circumMediterranean Triassic: phytogeographical and palaeoclimatological implications. Geologische Rundschau 70, 625-634.

Voigt, S., Hay, W.W., Höfling, R. \& DeConto, R.M. 1999: Biogeographic distribution of late Early to Late Cretaceous rudist-reefs in the Mediterranean as climate indicators. Geological Society of America Special Paper 332, 91-103.

Wahlman, G.P. 2002: Upper Carboniferous-Lower Permian (Bashkirian-Kungurian) mounds and reefs. SEPM (Society for Sedimentary Geology) Special Publication 72, 271-338.

Walter, H. 1985: Vegetation of the Earth and Ecological Systems of the Geo-biosphere, 3rd edn, 318 pp. Springer-Verlag, New York.

Wang, H.Z. 1985: Atlas of the Palaeogeography of China, 85 pp. Cartographic Publishing House, Beijing.

Wang, Z. 1993: Evolutionary ecosystem of Permian-Triassic redbeds in North China: a historical record of global desertification. In Lucas, S.G. \& Morales, M. (eds): The Nonmarine Triassic. New Mexico Museum of Natural History and Science Bulletin 3, 471-476.

Weidlich, O. 2002: Middle and Upper Permian reefs - distributional patterns and reservoir potential. SEPM (Society for Sedimentary Geology) Special Publication 72, 339-390.

Williams, G.E. 1989: Tidal rhythmites: geochronometers for the ancient Earth-Moon system. Episodes 12, 162-171.
Wilson, K.M., Pollard, D., Hay, W.W., Thompson, S.L. \& Wold, C.N. 1994: General circulation model simulations of Triassic climates: preliminary results. Geological Society of America Special Paper 288, 91-116.

Winguth, A.M.E., Heinze, C., Kutzbach, J.E., Maier-Reimer, E., Mikolajewicz, U., Rowley, D.B., Rees, P.M. \& Ziegler, A.M. 2002: Simulated warm polar currents during the Middle Permian. Paleoceanography 17, 1057.

Winterer, E.L. 1991: The Tethyan Pacific during Late Jurassic and Cretaceous times. Palaeogeography, Palaeoclimatology, Palaeoecology 87, 253-265.

Wolfe, J.A. 1985: Distribution of major vegetational types during the Tertiary. Geophysical Monograph 32, 357-375.

Woodroffe, C. 1992: Mangrove sediments and geomorphology. In Robertson, A.I. \& Alongi, D.M. (eds): Tropical Mangrove Ecosystems, 7-41. American Geophysical Union, Washington D.C.

Yao, Z.Q. 1983: Ecology and taphonomy of gigantopterids. Bulletin, Nanjing Institute of Geology and Palaeontology, Academia Sinica 6, 63-84 (in Chinese with English summary).

Yin, H.F. 1985: Bivalves near the Permian-Triassic boundary in South China. Journal of Paleontology 59, 572-600.

Zambrano Garcia, A. \& Weber, R. 1985: Nuevo ensayo de un panorama de la paleoecologia de comunidades de la tafoflora Santa Clara (Triasico tardio, Sonora). III Congreso Latinoamericano de Paleontologia, Memoria, 153-163.

Ziegler, A.M. 1990: Phytogeographic patterns and continental configurations during the Permian Period. In McKerrow, W.S. \& Scotese, C.R. (eds): Palaeozoic Palaeogeography and Biogeography. Geological Society Memoir 12, 363-379.

Ziegler, A.M., Barrett, S.F. \& Scotese, C.R. 1981: Palaeoclimate, sedimentation and continental accretion. Philosophical Transactions of the Royal Society of London A301, 253-264.

Ziegler, A.M., Gibbs, M.T. \& Hulver, M.L. 1998: A mini-atlas of oceanic water masses in the Permian period. Proceedings of the Royal Society of Victoria 110, 323-343.

Ziegler, A.M., Hulver, M.L., Lottes, A.L. \& Schmachtenberg, W.F. 1984: Uniformitarianism and palaeoclimates: inferences from the distribution of carbonate rocks. In Brenchley, P.J. (ed.): Fossils and Climate, 3-25. Wiley, New York.

Ziegler, A.M., Hulver, M.L. \& Rowley, D.B. 1997: Permian world topography and climate. In Martini, I.P. (ed.): Late Glacial and Post-Glacial Environmental Changes - Quaternary, Carboniferous-Permian and Proterozoic, 111-146. Oxford University Press, Oxford.

Ziegler, A.M., Raymond, A.L., Gierlowski, T.C., Horrell, M.A., Rowley, D.B. \& Lottes, A.L. 1987: Coal, climate and terrestrial productivity: the present and early Cretaceous compared. In Scott, A.C. (ed.): Coal and Coal-Bearing Strata: Recent Advances. Geological Society Special Publications 32, 25-49.

Ziegler, A.M., Rees, P.M. \& Naugolnykh, S.V. 2002: The Early Permian floras of Prince Edward Island, Canada: differentiating global from local effects of climate change. Canadian Journal of Earth Sciences 39, 223-238.

Ziegler, A.M., Rees, P.M., Rowley, D.B., Bekker, A., Qing, Li \& Hulver, M.L. 1996: Mesozoic assembly of Asia: constraints from fossil floras, tectonics, and paleomagnetism. In Yin, A. \& Harrison, T.M. (eds): The Tectonic Evolution of Asia, 371-401. Cambridge University Press, Cambridge.

Ziegler, A.M. \& Rowley, D.B. 1998: The vanishing record of epeiric seas with emphasis on the Late Cretaceous 'Hudson Seaway'. In Crowley, T.J. \& Burke K. (eds): Tectonic Boundary Conditions for Climate Reconstructions, 147-165. Oxford University Press, Oxford. 


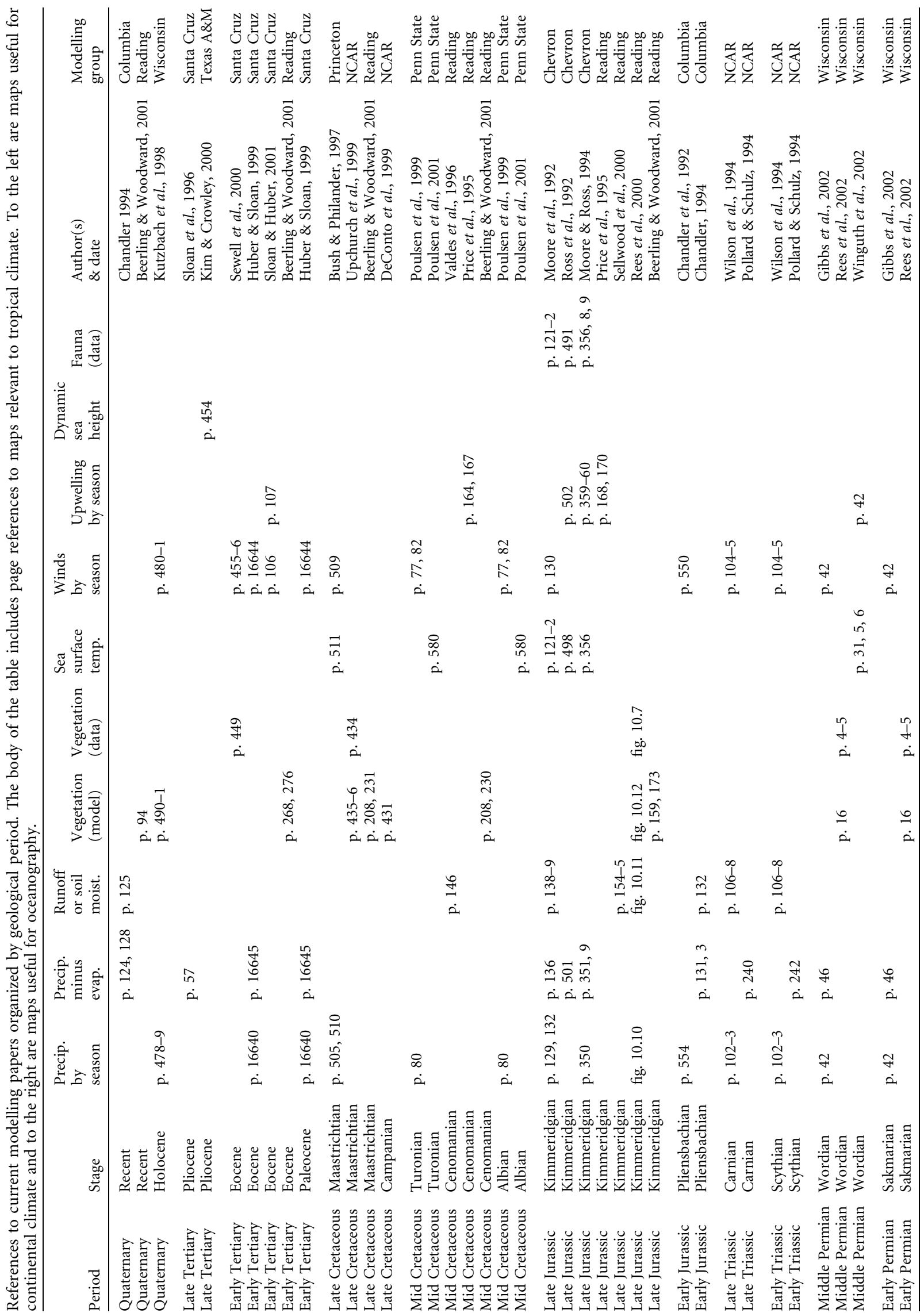

